GEOLOGICA BALCANICA 50 (1), Sofia, April 2021, pp. 45-65.

\title{
Exotic rock block from the Koshava gypsum mine, Northwest Bulgaria: Petrography, geochemistry, mineralogy and melting phenomena
}

\author{
Yotzo Yanev ${ }^{1}$, Aleksey Benderev ${ }^{1}$, Nikolai Zotov², Elena Dubinina ${ }^{3}$, \\ Tzvetoslav Iliev ${ }^{1}$, Stoyan Georgiev ${ }^{1}$, Iren Ilieva ${ }^{4}$, Ivanina Sergeeva ${ }^{1}$ \\ ${ }^{1}$ Geological Institute, Bulgarian Academy of Sciences, Acad. G. Bonchev Str., Bl. 24, 1113 Sofia, Bulgaria; \\ e-mails:yotzo_yanev@yahoo.com; aleksey@geology.bas.bg; tziliev@abv.bg; kantega@abv.bg; sergeeva.ivanina@gmail.com \\ ${ }^{2}$ University of Stuttgart, 70569 Stuttgart, Germany; e-mail: nikolay.zotov@f03.uni-stuttgart.de \\ ${ }^{3}$ Institute of Geology of Ore Deposits, Mineralogy, Petrography and Geochemistry (IGEM), Russian Academy of Sciences, \\ 119017 Moscow, 35/1 Staromonetnyi pereulok, Russian Federation; e-mail: elenadelta@gmail.com \\ ${ }^{4}$ Bulgarian Geological Society; e-mail: iren.ilieva812@gmail.com
}

(Accepted in revised form: April, 2021)

\begin{abstract}
The described exotic rock block $(60 \times 80 \times 13-15 \mathrm{~cm})$ was found at $290 \mathrm{~m}$ depth in a lower-middle Badenian gypsum layer in the Koshava mine, NW Bulgaria, near the Danube River. It is greyish-black, granular, with layered structure and layers composed of $\alpha$-quartz rosettes covered with organic matter (kerogen-like type with high contents of Ge, Mo and B), wood relicts with chalcedony replacement, and porous lenses with compact accumulation of organic matter. The block is coated with quartz crust, up to $2 \mathrm{~cm}$ thick, with regmaglypt-like forms, also replaced by quartz. Aside from the surface, melting phenomena were also observed inside the quartz rosettes and especially in the wood relicts and porous lenses. The melted drops are actually crystallized chalcedony. The organic matter accumulations contain Si-organic zoned micrometre-sized spherules. Fe silicides were found in the organic matter of all parts of the block, in which hapkeite was determined by X-ray analysis. Other detected minerals include graphite, cristobalite, coesite, skeletal and framboidal pyrite, moassanite, magnetite, suessite, sphalerite and minerals formed in the gypsum lagoon (gypsum, celestine, barite, calcite, halite and clays). The geological position of the block in the gypsum without any other sediments, the extensive melting phenomena with melted spherules, crushed quartz, its enrichment in ${ }^{18} \mathrm{O}$ isotope and the presence of coesite suggest that it is shock ejecta, in certain aspects resembling the large Muong Nong-type tektites, but its characteristics could be the basis for distinguishing it as a new tektite type. The fact that it was found in a gypsum layer of early-middle Badenian age points to its probable association with the Ries-Steinheim impact event, despite the long distance between them $(\sim 1100 \mathrm{~km})$.
\end{abstract}

Yanev, Y., Benderev, A., Zotov, N., Dubinina, E., Iliev, T., Georgiev, S., Ilieva, I., Sergeeva, I. 2021. Exotic rock block from the Koshava gypsum mine, Northwest Bulgaria: Petrography, geochemistry, mineralogy and melting phenomena. Geologica Balcanica 50 (1), 45-65.

Keywords: middle Miocene, organic matter, quartz oxygen isotopes, coesite, lechatelierite, Muong Nong-type tektite.

\section{INTRODUCTION}

The Koshava gypsum deposit is located in the Moesian Platform, near the Danube River in Northwest Bulgaria (Fig. 1). The gypsum layer is $25-30 \mathrm{~m}$ thick on the average, and it lies at depths from $95 \mathrm{~m}$ to $900 \mathrm{~m}$ (Trashliev et al., 1962). It is underlain by lower-middle Badenian marls and calcareous clays (Kojumdgieva et al., 1982). At places, it is also underlain by a thin package of sandstones and conglomerates, or even by Upper Cretaceous deposits. It is covered by $0.3-4 \mathrm{~m}$ thick layer of porous chem- 


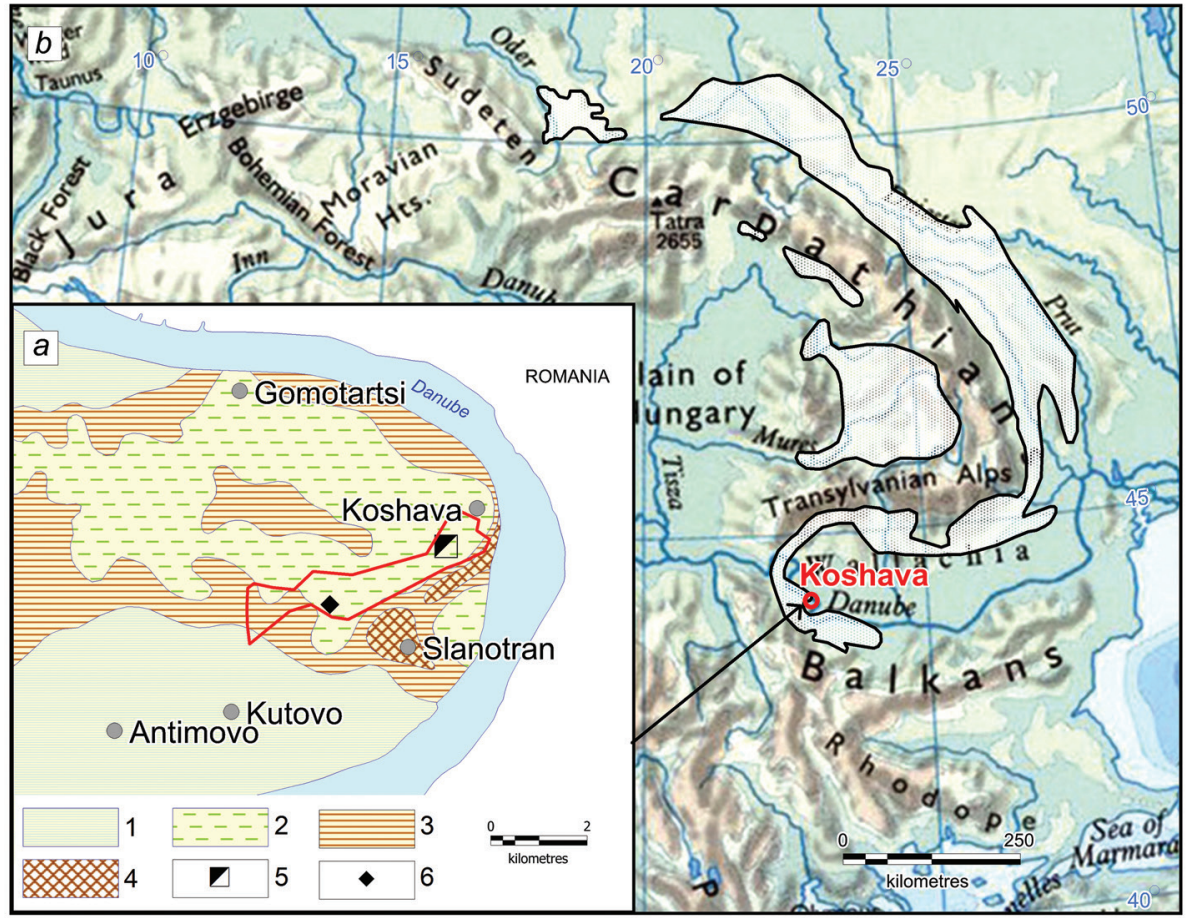

Fig. 1. a) Palaeogeographic map of the Badenian in the region of the Koshava gypsum deposit (red line), NW Bulgaria (after Trashliev, 1988). Legend: 1 - sea; 2 - lagoon; 3 - land covered later by the sea; 4 - land; 5 - pit; 6 - location of the Koshava exotic block. b) Sketch of Central and SE Europe, with location of the Badenian evaporites (in white, after De Leeuw et al., 2010) and the Koshava gypsum mine (red circle).

ogenic limestone, which is overlain, with an erosional surface, by upper Badenian clay or Sarmatian deposits. The gypsum formation is associated with the middle Badenian salt crisis that occurred in the Carpathian Fore-Deep from Poland in the north to NW Bulgaria in the south (Fig. 1b), generally attributed to the 15-14 Ma interval (Peryt, 2006, and references therein). Evaporites formed later in the northern part of the Fore-Deep (13.8-13.4 Ma, De Leeuw et al., 2010).

In the autumn of 2014, while mining the gypsum layer, an excavator came across a greyishblack rock block with dimensions $60 \times 80 \times 13-15$ cm (Yanev et al., 2015). It was located 5-6 m below the top of the gypsum layer, at $290 \mathrm{~m}$ below the surface, where no other sediment material, apart from gypsum, was observed. The coordinates of the location are $\mathrm{N} 44.052430^{\circ}$, E22.993142 ${ }^{\circ}$ (coordinate system WGS84 BL). The rock piece was broken by the excavator into several decimetre-sized fragments, some of which (Fig. 2a) were made available for study by the mining master Konstantin Antov. Another exotic block in the gypsum layer, which has the same color, structure and clear tree rings, was reported later by Petko Petrov of the National Museum 'Earth and Man', Sofia (pers. comm.).

Initial studies were undertaken (Yanev et al., 2015, 2016a, b) including petrographic, mineralogical and chemical analyses of one of the rock fragments. Due to the lack of isotopic analyses, two hypotheses were proposed for the provenance of this rock fragment based on the fact that it was found inside the uniform gypsum layer without other sediments, its composition and features (strong melting phenomena, regmaglypt-like forms, presence of pyrogenic minerals and alloys): (i) unusually large tektite; or (ii) Miocene stone meteorite of new, silica-carbonaceous type from a terrestrial type planet. To clarify its provenance (i.e., terrestrial or extraterrestrial), triple oxygen isotope study of the quartz was performed later (Dubinina et al., 2018), which determined its terrestrial origin.

The present paper summarises all petrographic, mineralogical, geochemical and isotopic data currently available for the Koshava exotic block. All analyses of the block were limited due to the destructive nature of the methods. 


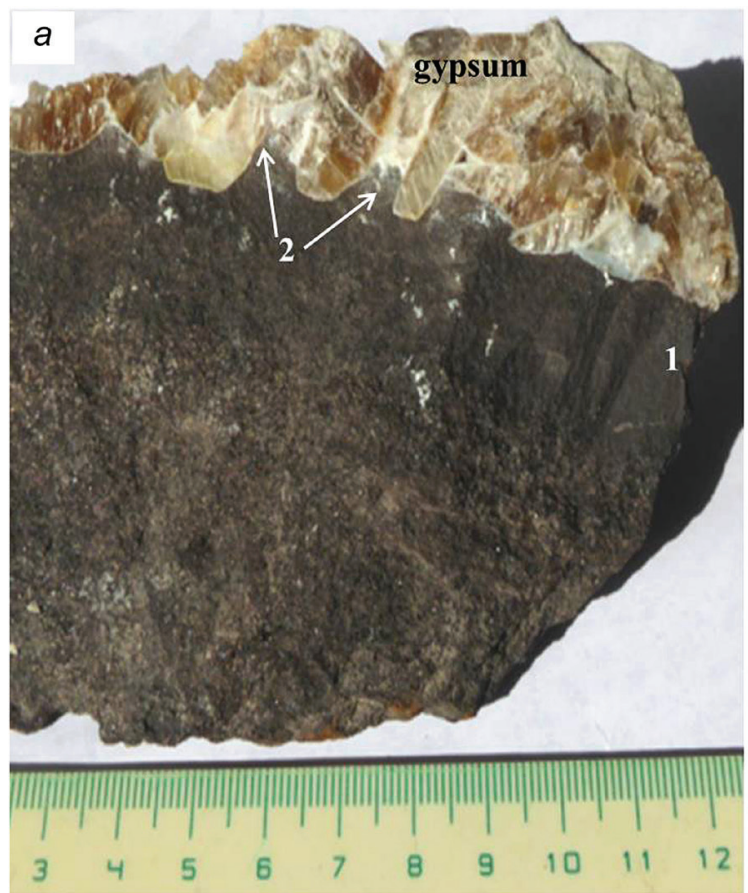

\section{METHODS}

Petrographic study was performed on polished thinsections from different parts of the Koshava rock block, using a Carl Zeiss Jena Amplival polarizing microscope. Microprobe analyses of thin-sections were carried out with a JEOL 733 Superprobe SEM and microprobe OPTEC System 5000 equipped with EDS (14 kV, $1 \mathrm{nA})$ at the Geological Institute of the Bulgarian Academy of Sciences (analyst $\mathrm{T}$. Iliev). The following Taylor standards were used: albite (s) for $\mathrm{Na}$, corundum (s) for Al, periclase (s) for Mg, quartz (s) for Si, pyrite (n) for S, Kfs (n) for $\mathrm{K}$, apatite (n) for Ca, rutile (s) for Ti, pyrolusite (n) for $\mathrm{Mn}$, hematite (n) for Fe, and glass (s) for $\mathrm{Ba}$. The silicide analyses are considered semi-quantitative due to the very small size of the crystals $(<5 \mu \mathrm{m})$ and the influence of the surrounding organic matter and quartz crystals.

X-ray diffraction study of two wall-rock samples from the solid layered part of the rock block (sample YY-M1) and another from the porous lenses (sample YY-M2) was performed with HR $X$ 'Pert diffractometer (Philips) at the Max Planck Institute in Stuttgart, equipped with a curved Ge monochromator in the primary beam and PANanalythical X'Celerator position sensitive detector, using $\mathrm{CuK}_{\alpha 1}$ radiation. X-ray diffraction study of the superficial crust and of the light and heavy fractions

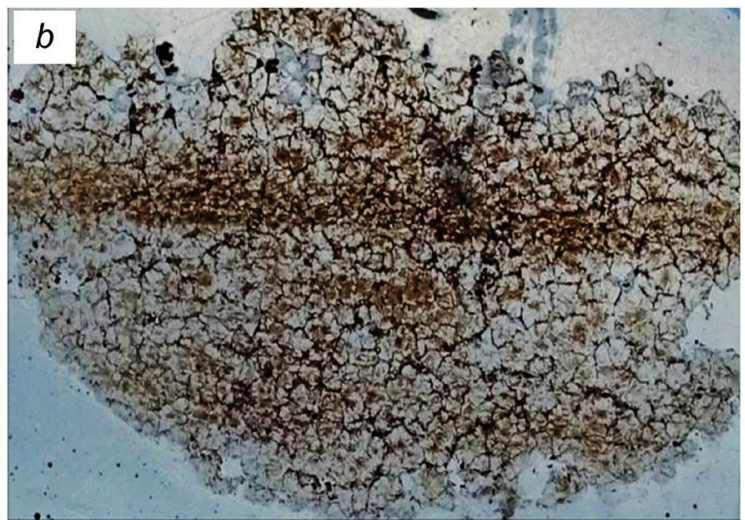

Fig. 2. a) One of the studied fragments of the Koshava rock block - superficial crust (1) with regmaglypt-like forms (2) covered by gypsum crystals. The white spots are porous gypsum. The scale ruler is in $\mathrm{cm}$. b) Photomicrograph of a thin-section ( $2.2 \mathrm{~cm}$ long) showing the layered structure of the rock (plane-polarized light); a detail is presented in Fig. $3 a, b$.

of sample YY-M1 was performed at the Geological Institute (analyst I. Sergeeva) with a HUBER Image Plate Guinier Camera G670, working in asymmetric transmission mode (Guinier geometry). Diffraction measurements were carried out with Ge monochromator on the primary beam, providing pure $\mathrm{Cu} \mathrm{K}_{\alpha_{1}}$ radiation, in the range of $2 \theta 4^{\circ}$ to $100^{\circ}$ simultaneously, and a step size of 0.005 . The exposure time was 30 minutes for all samples, with six scanning runs of the readout system. Collected diffraction data were analysed with Match! software package for phase identification, by CRYSTAL IMPACT, Bonn, Germany, with incorporated ICDD PDF-2 and COD databases.

The samples were crumbled between two cardboard surfaces to avoid contamination with iron particles and ground in an agate pestle.

The Raman spectra were obtained at the Max Plank Institute, Stuttgart, Germany, on a polished thin-section of sample YY-M1 with a single grating LabRAM HR800 (Jobin Yvon), using 532 nm laser excitation.

Major chemical elements of the organic matter in two wall-rock samples (YY-M1 and YY-M2) were determined, using Ultimate analysis (for $\mathrm{C}$ and $\mathrm{H}$ ) and Dumas method (for N) at the Institute of Organic Chemistry, Bulgarian Academy of Sciences (analyst R. Todorova). The other elements were analysed in polished sections with a JEOL 733 Super- 
probe SEM and microprobe OPTEC System 5000 equipped with EDS (14 kV, $1 \mathrm{nA})$ at the Geological Institute (analyst T. Iliev). Trace element analyses on seven spots of the quartz and three spots of the organic matter in sample YY-M1 were carried out, using a NWR Excimer $193 \mathrm{~nm}$ laser ablation system attached to a Perkin Elmer ELAN DRC-e LA-ICPMS at the same institute (analyst S. Georgiev). Spot diameter was $35 \mu \mathrm{m}$ and laser frequency $-4 \mathrm{~Hz}$. The NIST SRM 610 glass was used as external standard.

Isotope analysis was performed on one sample from the massive, layered part of the Koshava rock block (sample YY-M1) at the Institute of Geology of Ore Deposits, Mineralogy, Petrography and Geochemistry (IGEM), Russian Academy of Sciences, Moscow, using the laser fluorination technique (Sharp, 1990). $\mathrm{BrF}_{5}$ was used as reagent to extract oxygen from the quartz according to the reaction:
$\mathrm{SiO}_{2}+\mathrm{BrF}_{5}=\mathrm{SiF}_{4}+\mathrm{O}_{2}+\mathrm{BrF}$. To remove the organic matter before the analysis, the crushed sample was boiled for 12 hours in concentrated $\mathrm{H}_{2} \mathrm{O}_{2}$. After boiling, it was left in hydrogen peroxide for approximately $48 \mathrm{~h}$. This treatment allowed to obtain almost clear quartz grains without organic matter. Four portions (1-1.5 mg) from the same sample were measured by laser fluorination technique.

The samples were heated by $30 \mathrm{~W}$ infrared $\left(\mathrm{CO}_{2}\right)$ laser (New Wave Research, USA) in a $\mathrm{BrF}_{5}$ atmosphere. The obtained oxygen was purified, using cryogenic traps, and the purified analyte was injected in the dual inlet system of mass-spectrometer DeltaPlus (Thermo, Germany). The measurements were carried out relative to in-house $\mathrm{O}_{2}$ calibrated gas at the V-SMOW scale, relatively both NBS 28 quartz and UWG-2 garnet standards (Valley et al., 1995). The accuracy of $\delta^{18} \mathrm{O}$ and $\delta^{17} \mathrm{O}$ values obtained was better than $\pm 0.1 \%$.
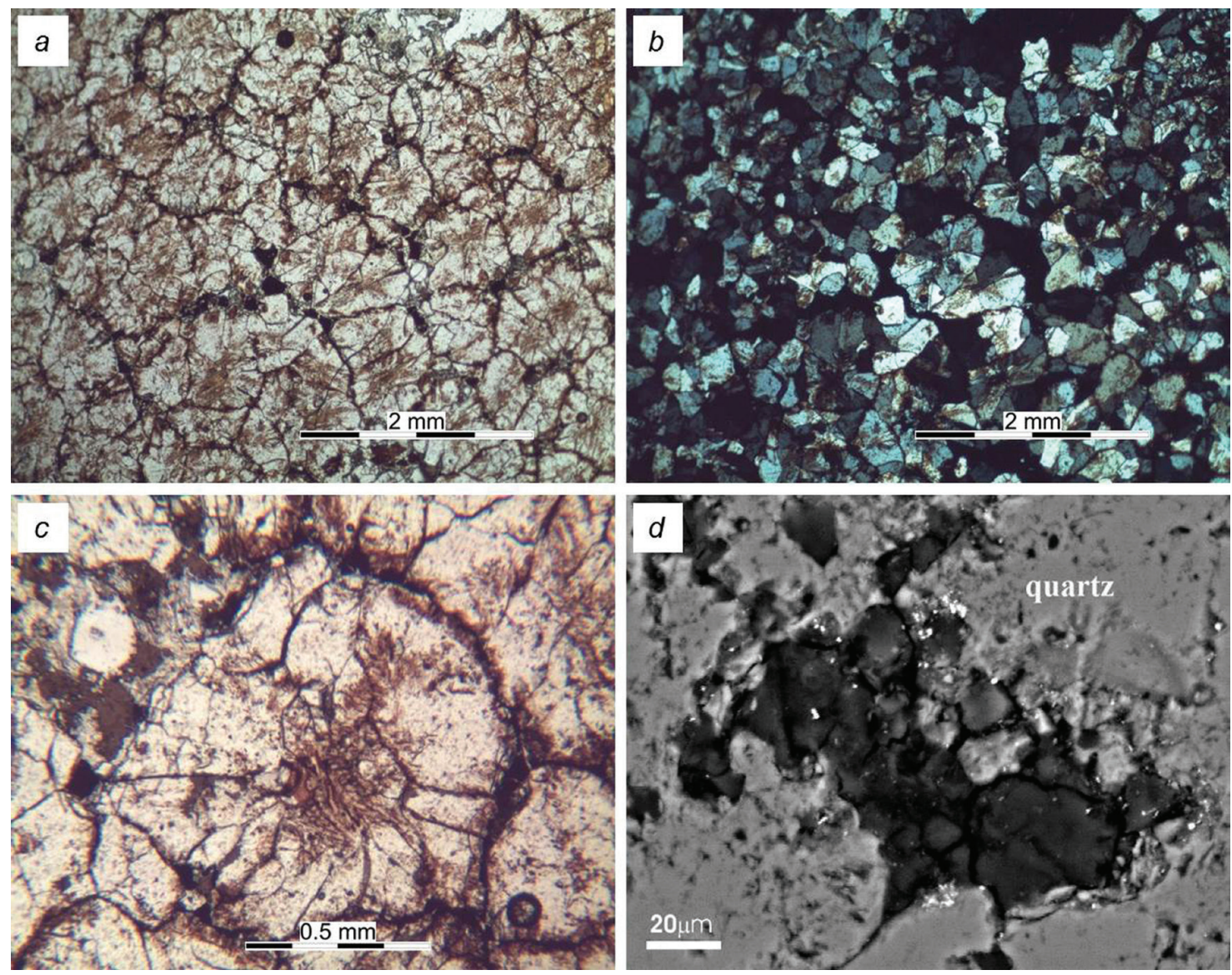

Fig. 3. $a, b$ ) Photomicrographs showing the texture of the Koshava rock block - quartz rosettes with dark organic matter between them. c) Quartz rosette surrounded the organic matter with 'grille' of chalcedony droplets in the rosette centre ( $a, c-$ plane-polarized light; $b$-cross-polarized light). $d$ ) Back-scattered electron (BSE) image of an accumulation of organic matter droplets (black) surrounded by molten quartz 'walls'. The bright points are micrometre-sized Fe silicide crystals. 


\section{PETROGRAPHIC DESCRIPTION}

The rock block has greyish-black matt surface, not glassy (see below), and often with regmaglypt-like forms (Fig. 2a). It is heterogeneous and has fine-layered texture, with 1-2 mm wide, compact granular layers alternating with fine ones of 5-10 $\mu \mathrm{m}$ thickness (Fig. 2b). The compact layers are composed of irregular 4-, 5- and 6-angular rosette-like quartz aggregates $(0.1-1 \mathrm{~mm}$ in size, Fig. $3 a, b)$. The size of the individual crystals is up to $0.5 \times 0.25 \mathrm{~mm}$. Very often, a 'grille' of micrometre-sized chalcedony droplets can be observed in the rosette centre (Fig. 3c).

The interstices between the rosettes are filled with a brown-black (under optical microscope) thin film of amorphous mass, very often penetrating the fissures in the quartz crystals. This matter forms aggregated droplets at places, 5-25 $\mu \mathrm{m}$ in diameter each (Fig. $3 d$ ). On the periphery of these aggregates, there are micrometre-sized Fe-silicide crystals (see below). Quadrangular, rectangular, 5- or 6-angular forms $(0.1-0.2 \mathrm{~mm})$ are observed in the interstices (Fig. 4), resembling graphite or fullerite (as reported by Krätschmer et al., 1990). The amorphous nature of this matter has been confirmed by microRaman spectroscopy. The obtained spectra (Yanev et al., 2016b) of this amorphous mass (Fig. $5 a$ ) show two broad bands at $1390 \pm 4 \mathrm{~cm}^{-1}\left(\mathrm{FWHM}=125 \pm 4 \mathrm{~cm}^{-1}\right)$ and $1582 \pm 1 \mathrm{~cm}^{-1}\left(\mathrm{FWHM}=47.4 \pm 1.6 \mathrm{~cm}^{-1}\right)$ called D ('disordered') and G ('graphite'), respectively (e.g., Wopenka and Pasteris, 1993; Bussemann et al., 2007) with $I_{D} / I_{G}=0.9$. Their large width permits to attribute the $\mathrm{D}$ band to the disordered polyaromatic organic matter (kerogen-like). The position of the $G$ band, very close to $1581 \mathrm{~cm}^{-1}$ (graphite band), and the width $<50 \mathrm{~cm}^{-1}$ indicate an onset of graphitization (presence of some graphitic domains). Graphite spectrum is found in the quartz rosettes characterized by a very narrow $\mathrm{G}$ peak (Fig. $5 b$ ).

The fine layers are 5-10 $\mu \mathrm{m}$ thick (Fig. $2 b$ ) and composed of quartz grains or irregular quartz rosettes, which are smaller and not as well shaped as the rosettes in the broader layers. Some of the fine layers, as well as some bands perpendicular to them (Fig. 6a, b), are relicts with wood texture (Fig. 6c, d), similar to the textures described by Iamandei et al. (2014) in Oligocene petrified trees from the Eastern Rhodopes Mountains. The wood texture in the Koshava block is perpendicular to its visible layering. This texture is composed of parenchyma cells constituting ground tissue, often polyhedral and up to $0.005 \mathrm{~mm}$ in diameter, with rounded to polygonal vessels up to $0.1 \mathrm{~mm}$ in diameter. The periphery of the relict bands is made of quartz rosettes; in some places between them, there remain relicts of wood texture. All elements in the wood texture are replaced by chalcedony radial aggregates, with cristobalite at places (Fig. 6d). The chalcedony does not follow the wood texture in some cases. Occa-
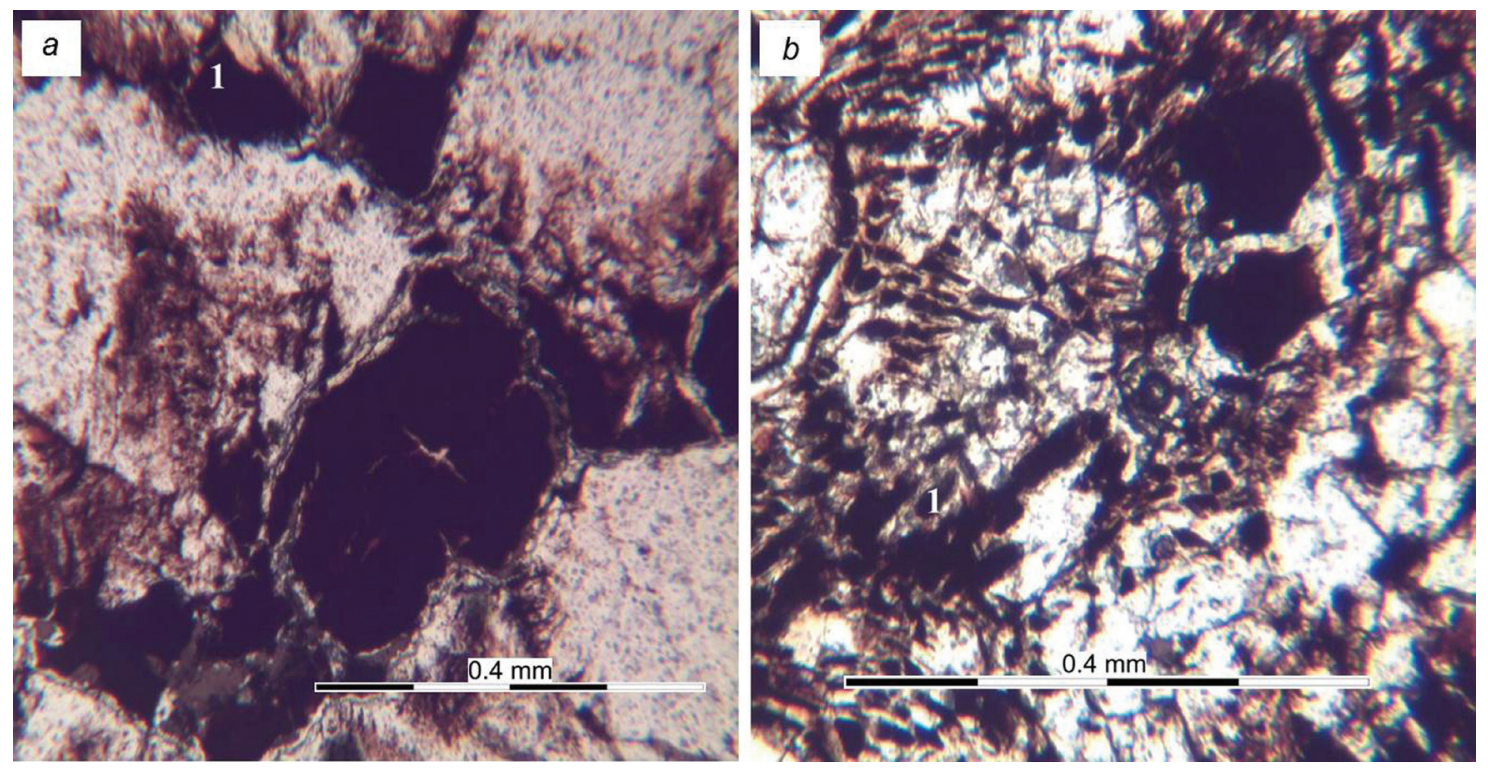

Fig. 4. $a, b$ ) Photomicrographs of an unidentified mineral (graphite or fullerite, now amorphous) in the interstices between the quartz rosettes (plane-polarized light). Legend: 1 - organic matter. 
sionally, there are chalcedony lenses of millimetre size and irregular shape or short veinlet up to $1 \mathrm{~cm}$ long. In the relict areas, the organic matter forms in-

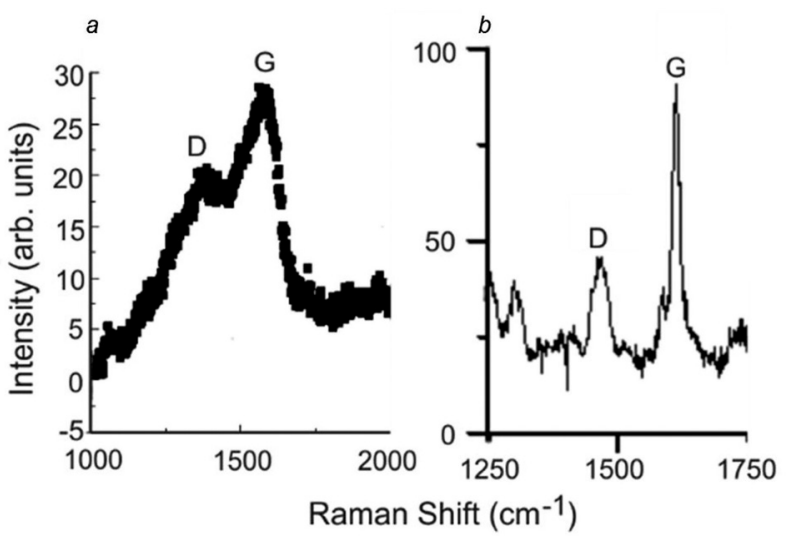

Fig. 5. Raman spectra of the organic matter in the Koshava rock block $(a)$ and of graphite in the quartz rosettes $(b)$. Legend: D - 'disordered' bands; G - 'graphite' bands. See text for explanation. terrupted bands, 0.2-0.5 mm apart and composed of micrometre-wide dark ribbons. These bands extend into the organic matter between the quartz rosettes (Fig. 6b).

Porous lenses are observed directly under the crust on the block (Figs $2 a, 7 a, b$ ). In the upper part of the block, these lenses are 10-15 cm long and 3-4 cm wide. In the lower parts of the block, they are substantially smaller - up to 3-4 cm long, of irregular shape and directly covered by gypsum, i.e., without surface crust (Fig. $7 b$ ). The walls of the lenses have dendritic-like texture. These walls are composed of the wood relicts described above, partially replaced by quartz rosettes and severely deformed by melting phenomena (described below). The lenses are very porous, rich in organic matter, presently leached in many cases, with quartzose wood relicts and abundant melting products. The lenses contain compact agglomerations of organic matter, up to 2-3 cm in size, which are interpreted as the likely result of tree carbonation.
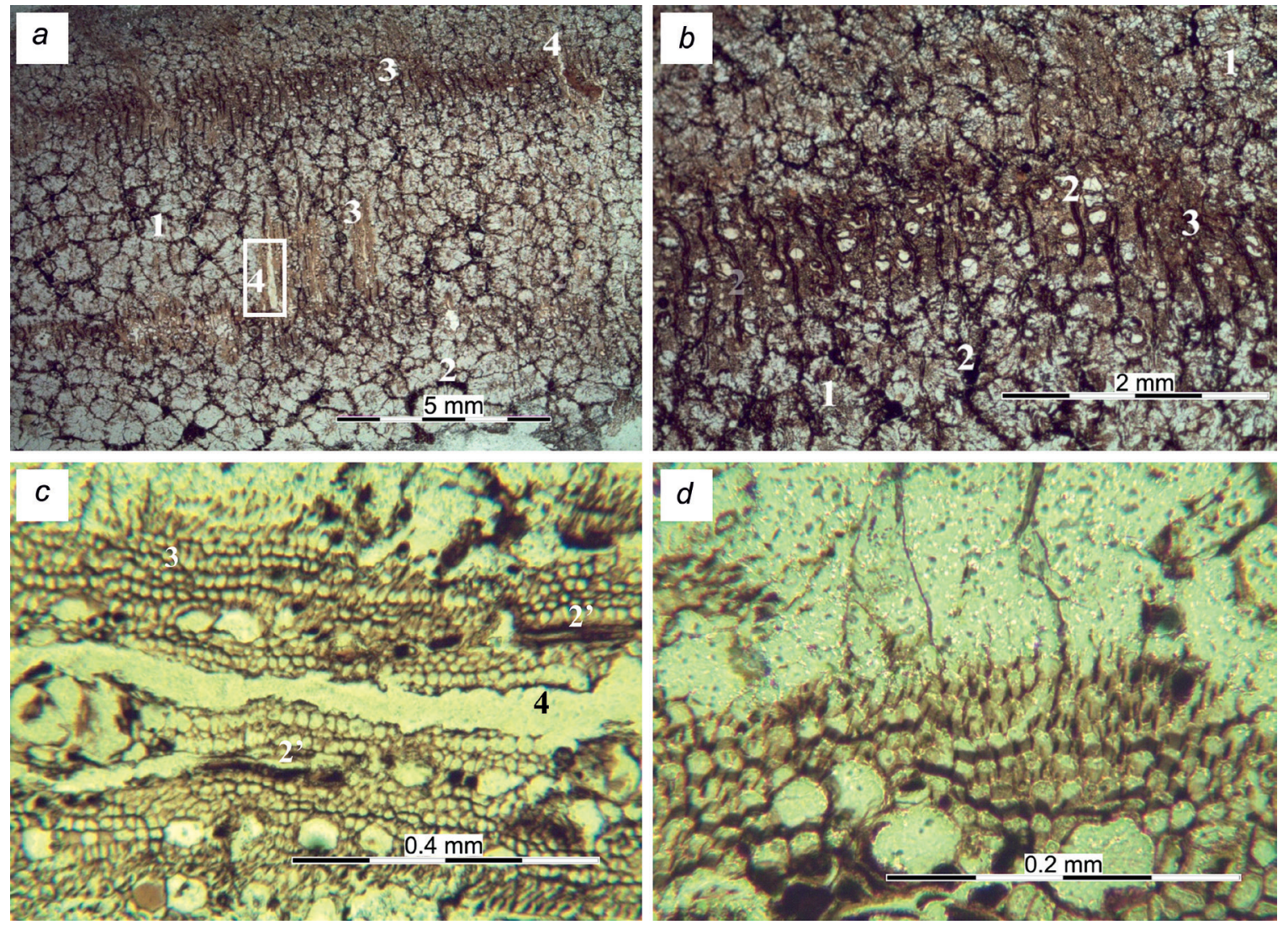

Fig. 6. Photomicrographs (plane-polarized light) of: $a, b$ ) layered texture of the Koshava rock block: 1 - quartz rosettes; 2 - organic matter between them; 3 - relict of petrified wood replaced by chalcedony; 4 - chalcedony vein; $c$ ) a detail of the relict of petrified wood (shown in Fig. $6 a$ as a rectangle): 2' - broken rays of organic matter; $d$ ) zoomed on (c) where cristobalite micrometre-sized crystals (bright spots) are visible. 

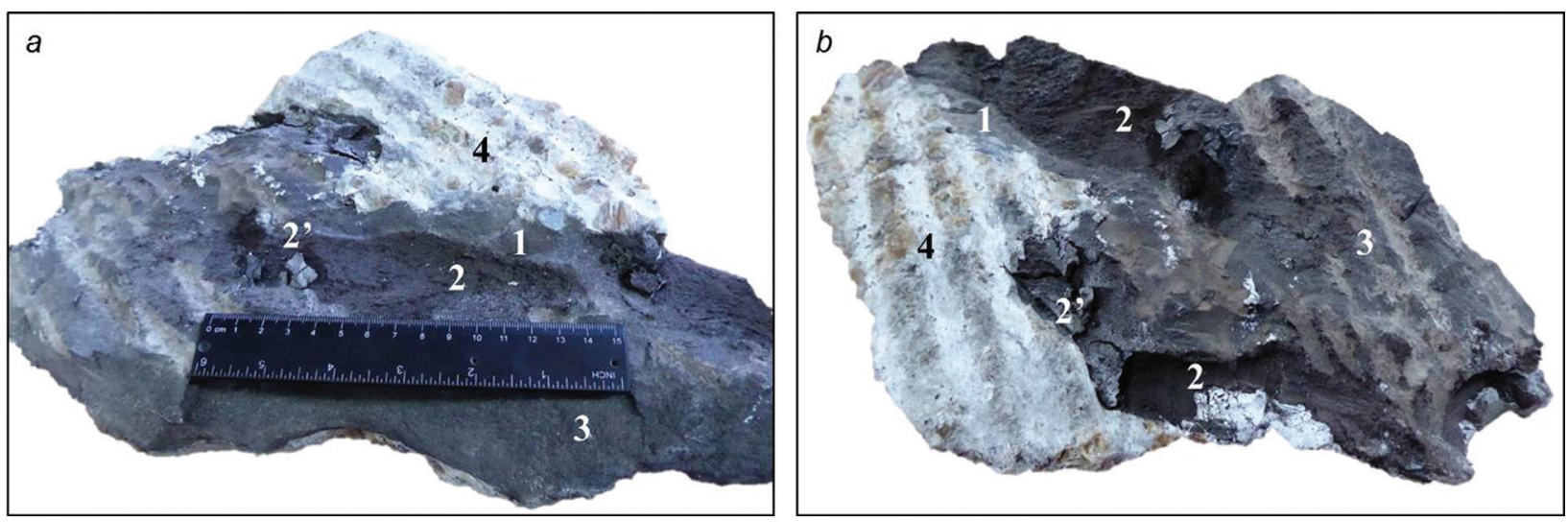

Fig. 7. Two views of the second fragment of the Koshava rock block with the following zones: 1 - superficial crust with regmaglypt-like forms; 2 - porous lenses with organic matter in a compact accumulation (2'); 3 - layered part of the block; 4 - gypsum. The scale ruler is in $\mathrm{cm}$ (above) and in inch (below). The large stripes on the rock block were made by a mine excavator.

\section{CHEMICAL COMPOSITION OF THE ORGANIC MATTER}

The organic matter in the massive layered part of the rock block is $5.55 \mathrm{wt} \%$ (Yanev et al., 2016a) according to the elemental analysis of one sample (YY-M1). The concentration of major elements in the organic matter is presented in Table 1 . The
ERMA result shows clear prevalence of sulphur among the other minor elements. The concentration of $\mathrm{Cl}$ correlates to $\mathrm{Na}$ and $\mathrm{K}$ ( $\mathrm{r}=0.63$ and 0.65 , correspondingly; $n=11$ ), which could be associated with the presence of halite (Yanev et al., 2015) and possibly sylvite. There is also correlation between $\mathrm{S}$ and $\mathrm{Ca}(\mathrm{r}=0.81)$, possibly due to the presence of gypsum and/or oldhamite. The composition of the

Table 1

Microprobe and elemental analyses (wt\%) of the organic matter of sample YY-M1 from the Koshava exotic rock block

\begin{tabular}{lccc|ccccc}
\hline \multirow{3}{*}{ Samples } & \multicolumn{3}{c|}{ YY-M1 } & \multicolumn{5}{c}{ YY-M2 } \\
\cline { 2 - 9 } & $\begin{array}{l}\text { average } \\
(\mathrm{n}=10)\end{array}$ & min & $\max$ & 1 & 2 & 3 & 4 & 5 \\
\hline $\mathrm{S}$ & 5.00 & 4.75 & 5.57 & 0.30 & 4.04 & 4.10 & 5.43 & 6.07 \\
$\mathrm{Si}$ & 0.26 & 0.11 & 0.49 & 1.60 & 0.05 & 0.09 & 0.05 & 0.18 \\
$\mathrm{Al}$ & n.d. & n.d. & n.d. & n.d. & n.d. & 0.01 & 0.46 & 0.43 \\
$\mathrm{Fe}$ & n.d. & n.d. & n.d. & 0.29 & n.d. & n.d. & 0.16 & n.d. \\
$\mathrm{Mg}$ & 0.20 & 0.11 & 0.25 & n.d. & 0.09 & 0.10 & 0.28 & 0.35 \\
$\mathrm{Ca}$ & 1.09 & 0.87 & 1.34 & 0.15 & 1.39 & 2.06 & 1.07 & 1.31 \\
$\mathrm{Na}$ & 0.91 & 0.68 & 1.21 & 0.41 & 0.12 & 0.03 & 1.72 & 1.18 \\
$\mathrm{~K}$ & 0.68 & 0.38 & 0.89 & 0.14 & n.d. & n.d. & 0.04 & 0.12 \\
$\mathrm{Cl}$ & 0.90 & 0.69 & 1.11 & 1.16 & n.d. & n.d. & 3.12 & 3.31 \\
Total & 9.04 & 7.59 & 10.86 & 4.05 & 5.69 & 6.39 & 12.33 & 12.95 \\
\hline $\mathrm{C}^{*}$ & 69.84 & & & & & & \\
$\mathrm{H}^{*}$ & 13.59 & & & & & & & \\
$\mathrm{~N}^{* *}$ & 7.53 & & & & & & &
\end{tabular}

YY-M1 - organic matter in the interstices between the quartz rosettes

YY-M2 - organic matter of the compact accumulation in the porous lenses: 1- veins;

2, 3 - microlenses; 4, 5 - "ground mass"

* Ultimate analysis

** Dumas method.

n.d. - not detected 


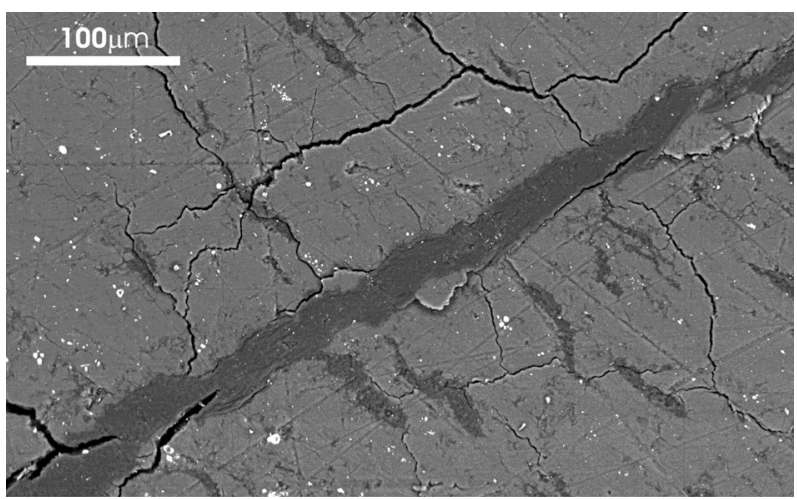

Fig. 8. BSE image of organic matter in a compact accumulation with different composition (see text for explanation and Table 1). The bright points are micrometre-sized Fe silicides, and the round ones are framboidal pyrite (see also Fig. 15).

organic matter in one sample (YY-M2) of the porous lenses is (in $w t \%)$ : 68.42 for carbon, 8.45 for hydrogen, 2.14 for nitrogen, and oxygen. Here, the organic matter of the compact accumulations is heterogeneous (Fig. 8), containing up to $25 \mu \mathrm{m}$ thick veinlets, severely flattened microlenses or xenomorphic spots with different composition (Table 1). This organic matter has relatively high concentrations of $\mathrm{S}, \mathrm{Cl}$ and $\mathrm{Na}$, as well as significantly less $\mathrm{C}+\mathrm{H}+\mathrm{N}$ (assumed as loss in ERMA). Likewise, there is a positive correlation between $\mathrm{Cl}$ and $\mathrm{Na}$ $(\mathrm{r}=0.95 ; \mathrm{n}=5)$ and $\mathrm{K}(\mathrm{r}=0.59)$, and between $\mathrm{S}$ and $\mathrm{Ca}(\mathrm{r}=0.65)$. The correlation between organic matter (as $\mathrm{C}+\mathrm{H}+\mathrm{N})$ and $\mathrm{S}$ is negative $(\mathrm{r}=-0.85)$, probably due to the presence of sulphur or sulphides with nano dimensions.

Table 2 and Fig. $9 a$ show the concentration of trace elements in the organic matter from the interstices between the quartz rosettes in sample YY-M1 (Yanev et al., 2016a). The elements in the figure are grouped in terms of their corresponding Coal Affinity Index (CAI, Ketris and Yudovich, 2009), which represents the ratio between the concentration of a given chemical element in brown coals and in sedimentary rocks. The studied organic matter is very rich in a number of trace elements (in ppm): Ge (1109) and Mo (32.2) in the first place (highly coalphile elements, CAI $>5$ ), but also B (185), Zn (36.23) and W (12.7) (coalphile elements, CAI $2-5)$. However, other coalphile $(\mathrm{Pb})$ and moderately coalphile (Hf, Co, Ba, Sc, Nb, Ga, LREE, especially $\mathrm{Ti}$ and $\mathrm{P}$ ) elements have concentrations lower than world coal values. We interpret the relatively high concentration of $\mathrm{Cl}$ (non-coalphile element with $\mathrm{CAI}<1$ ) in the organic matter (Table 1 ) as the result of the presence of halite (see above).
Table 2

Major (wt\%) and trace (ppm) element composition (laser ablation analysis) of the organic matter in the Koshava exotic rock block (YY-M1 sample)

\begin{tabular}{|c|c|c|}
\hline Elements & $\begin{array}{c}\text { Average } \\
(\mathrm{n}=3)\end{array}$ & Single analysis \\
\hline $\mathrm{Ti}$ & $<0.002$ & $0.002 \pm 0.0005$ \\
\hline $\mathrm{Al}$ & $0.103 \pm 0.002$ & \\
\hline $\mathrm{Fe}$ & $0.145 \pm 0.007$ & \\
\hline Mn & $0.003 \pm 0.0002$ & \\
\hline $\mathrm{P}$ & $<0.0016$ & $0.0065 \pm 0.0026$ \\
\hline B & $185.00 \pm 13.71$ & \\
\hline Sc & $<5.87$ & \\
\hline $\mathrm{V}$ & $46.09 \pm 1.86$ & \\
\hline $\mathrm{Cr}$ & $<84.67$ & $117.84 \pm 19.50$ \\
\hline Co & $<0.93$ & \\
\hline $\mathrm{Ni}$ & $<29.06$ & $23.46 \pm 8.14$ \\
\hline $\mathrm{Cu}$ & $19.07 \pm 3.00$ & \\
\hline $\mathrm{Zn}$ & $36.23 \pm 9.91$ & \\
\hline $\mathrm{Ga}$ & $<1.78$ & \\
\hline $\mathrm{Ge}$ & $1109.25 \pm 27.51$ & \\
\hline As & $<11.10$ & \\
\hline $\mathrm{Sr}$ & $190.57 \pm 2.46$ & \\
\hline $\mathrm{Y}$ & $12.56 \pm 0.60$ & \\
\hline $\mathrm{Zr}$ & $12.52 \pm 0.85$ & \\
\hline $\mathrm{Nb}$ & $<0.41$ & $0.25 \pm 0.13$ \\
\hline Mo & $32.19 \pm 3.46$ & \\
\hline $\mathrm{Ag}$ & $<0.50$ & \\
\hline Sn & $<2.78$ & \\
\hline $\mathrm{Sb}$ & $<2.02$ & \\
\hline $\mathrm{Ba}$ & $11.91 \pm 1.76$ & \\
\hline $\mathrm{La}$ & $1.14 \pm 0.19$ & \\
\hline $\mathrm{Ce}$ & $3.08 \pm 0.31$ & \\
\hline $\operatorname{Pr}$ & $0.50 \pm 0.13$ & \\
\hline $\mathrm{Nd}$ & $<2.53$ & $2.95 \pm 0.67$ \\
\hline $\mathrm{Sm}$ & $<2.03$ & $1.96 \pm 0.73$ \\
\hline Eu & $0.37 \pm 0.15$ & \\
\hline Gd & $<2.53$ & $1.66 \pm 0.55$ \\
\hline $\mathrm{Tb}$ & $<0.17$ & $0.21 \pm 0.09$ \\
\hline Dy & $1.69 \pm 0.46$ & \\
\hline Ho & $<0.36$ & $0.47 \pm 0.11$ \\
\hline Er & $2.00 \pm 0.53$ & \\
\hline $\mathrm{Tm}$ & $<0.28$ & $0.30 \pm 0.10$ \\
\hline $\mathrm{Yb}$ & $<1.58$ & $2.18 \pm 0.68$ \\
\hline $\mathrm{Lu}$ & $0.32 \pm 0.10$ & \\
\hline $\mathrm{Hf}$ & $<0.50$ & \\
\hline Та & $<0.27$ & \\
\hline W & $12.72 \pm 1.35$ & \\
\hline $\mathrm{Pb}$ & $<2.18$ & $2.38 \pm 0.51$ \\
\hline
\end{tabular}

The REE distribution pattern is very different from that of the brown coals (Fig. 9b): very limited differentiation $\left(\mathrm{La}_{\mathrm{n}} / \mathrm{Lu}_{\mathrm{n}}=0.37\right)$, depletion of the LREE and MREE, a little enrichment of HREE with a positive Sm anomaly. The negative Eu anomaly corresponds to those in the coals. 

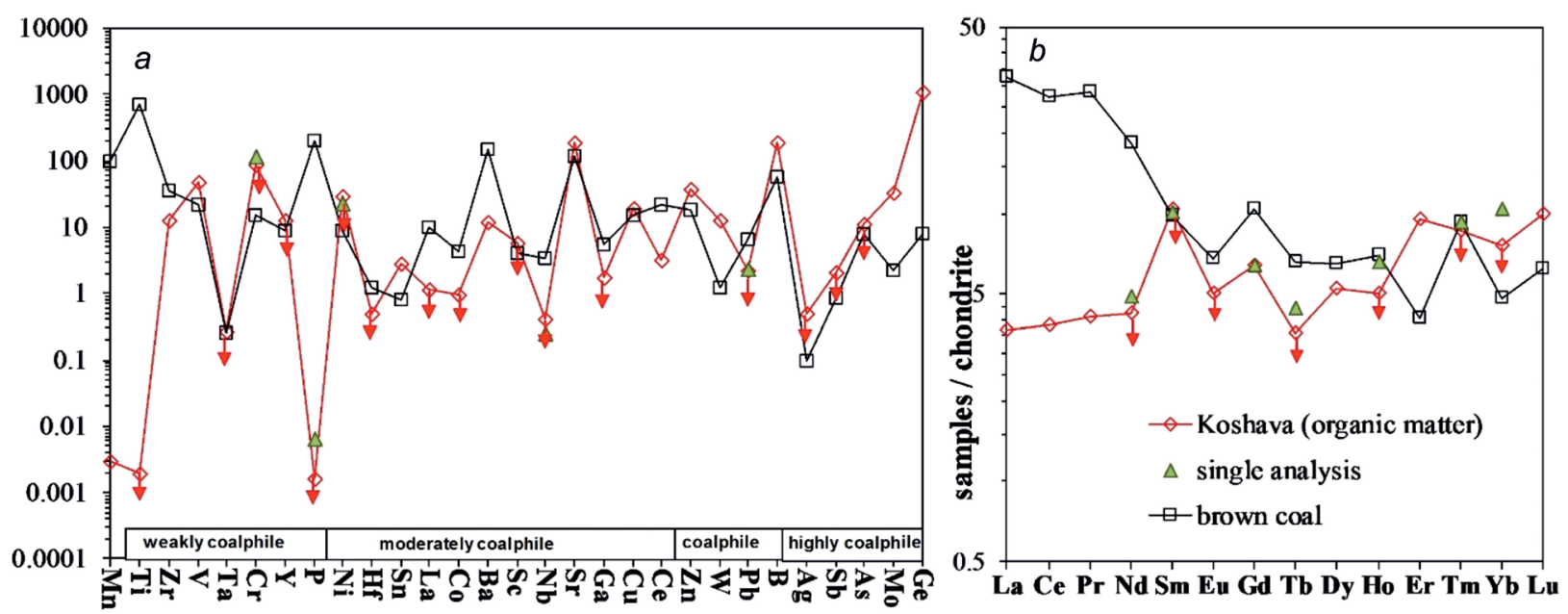

Fig. 9. a) Trace element contents in ppm (according to Table 2). (b) REE normalized contents (normalizing value from Boynton, 1984) in the organic matter of the Koshava rock block (red squares - average of three analyses; green triangles - single analysis), compared with the average world values of brown coals after Ketris and Yudovich (2009). See text for explanation. Note: the red arrows show that the average content contains analysed spots below detection limit.

\section{MELTING PHENOMENA}

Three zones can be distinguished in the rock block, characterized by different degrees of melting: (i) superficial crust; (ii) the layered rock block, composed of quartz rosettes; and (iii) porous lenses (Fig. 7a,b).

\section{Superficial crust}

The superficial crust is up to $2 \mathrm{~cm}$ thick, massive, greyish-black and composed of three narrow subzones (Fig. 10a): (1) regmaglypt-like forms and the external surface of the rock, which gradually merges with (2) a fine-grained quartz band (up to $3 \mathrm{~mm}$ thick), followed by (3) a quartz-chalcedony-organic subzone (1.5-1.7 cm thick). The regmaglypt-like forms (Fig. 10b, $c$ ) are up to 5-7 $\mathrm{mm}$ in height and composed essentially of hypidiomorphic quartz crystals, $0.05-0.1 \mathrm{~mm}$ in cross-section with micrometre-sized cristobalite crystals (Fig. 10d). Single skeletal crystals of probable graphite and Fe-silicides (see below) can be seen between the quartz crystals and also very rare, fine bands or globules of black, possibly organic, matter. Only the external crust of the regmaglypts and the external micrometre-wide band of the rock block are composed of a single sheet of pure quartz crystals without organic matter. The second subzone (Fig. 10b) is fine-grained and composed of xenomorphic quartz crystals with undulose extinction and similar size as the crystals described above; between them, there are agglom- erations or fine bands of organic matter. It could be assumed that the quartz in those two subzones had crystallized from the glass crust that was formed on the external surface of the rock block. The third subzone is the widest (Fig. 11). The quartz rosettes were melted to spherical or xenomorphic forms presently filled with chalcedony or quartz with undulose extinction. The organic matter forms continuous bands (Fig. 11a), which are $0.2-0.5 \mathrm{~mm}$ apart. They are composed of micrometre-sized filaments. These bands define the texture of all subzones. 'Draperies' of organic matter extend from the bands over the quartz crystals, consisting of extremely fine hairlike fibers. There are also areas of molten rosettes, up to $0.5 \mathrm{~mm}$ in size, presently composed of hypidiomorphic quartz with dimensions of $0.05-0.07 \mathrm{~mm}$ (Fig. 11b) and containing cristobalite microcrystals (Fig. 11c). The organic matter forms spherical to ellipsoidal globules in these areas, or is in the form of short bands. Skeletal or colomorphic pyrite (Fig. 11d) and Fe silicides (see below) are visible between the quartz crystals.

In this zone, there are also millimetre-wide lenses or short veinlets of chalcedony. No distinct boundary exists between this subzone and the next part of the rock block described below (Fig. 10a).

\section{Rock block}

Within the rock block, melting phenomena can be observed in the central parts of the quartz rosettes, where 'lattices' are formed by chalcedony drop- 

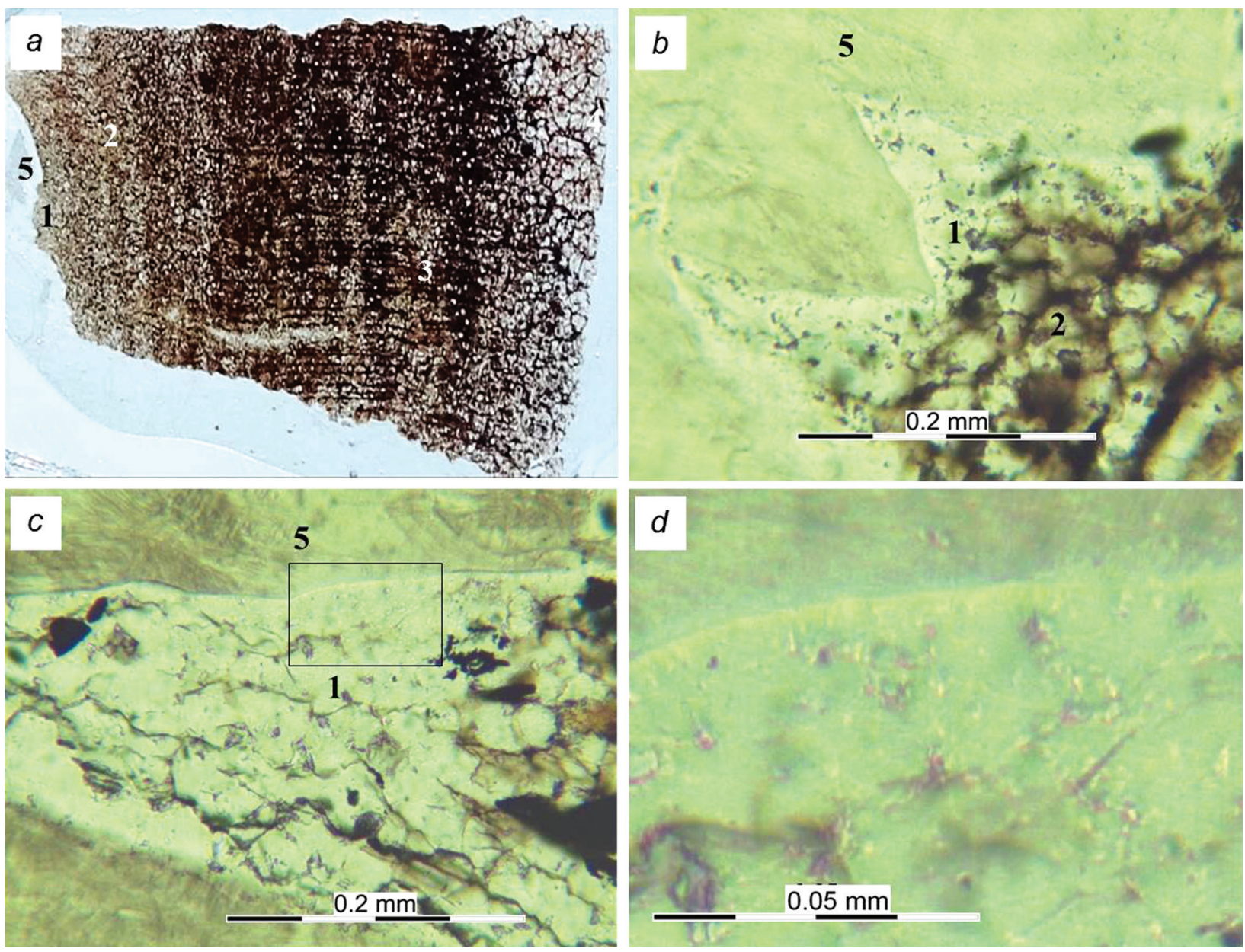

Fig. 10. Photomicrographs (plane-polarized light) of: $a$ ) thin-section ( $2 \mathrm{~cm}$ long) of the superficial crust with the following subzones: 1 - outermost crust with regmaglypt-like forms; 2 - fine quartz subzone; 3 - quartz-chalcedony subzone with organic 'draperies'; 4 - zone of quartz rosettes; 5 - gypsum. $b$ ) Detail of the first (with regmaglypts) and second subzones. The opaque grains are pyrite, Fe silicides and organic matter. $c$ ) Regmaglypt-like form replaced by quartz. The opaque grains are Fe silicides, organic matter and, probably, graphite. $d$ ) Zoomed on the rectangle in (c), where micrometre-sized cristobalites (bright spots) are visible.

like forms (Fig. 3c). Similar textures have been described in the centre of cristobalite globules of the socalled Libyan Impact Glass (Fröhlich et al., 2013). The quartz crystals of the rosettes have mosaic extinction pattern in places or $2-3$ systems of lamellae, probably formed by deformation (Fig. 12a), or are extensively cracked (Fig. 12b). As mentioned above, the organic matter between the rosettes has become fully amorphous.

The melting phenomena are most distinct in the bands with relicts of wood texture (Fig. 6b). Numerous micrometre-sized cristobalite crystals are observed in the quartz rosettes around the deformed wood remains, as well as in the chalcedony replacement (Fig. 6d). The ground-tissue cells of the wood texture are severely deformed (Fig. 6b). In some plac- es, the wood texture is ruptured by later formation of quartz crystals, or by chalcedony globules with droplets of organic matter, or filled with chalcedony coloured by dispersed organic matter (Fig. 6c). The bands of organic matter are either broken or severely twisted. In the areas around them in the centre of the quartz rosettes, there can be observed chalcedony globules instead of the aforementioned lattices (Fig. 6b).

\section{Porous lenses}

The porous lenses are composed of partially melted quartz rosettes with relicts of wood texture also deformed by melting, similar to the phenomena described above. Here, parenchyma cells, building the 

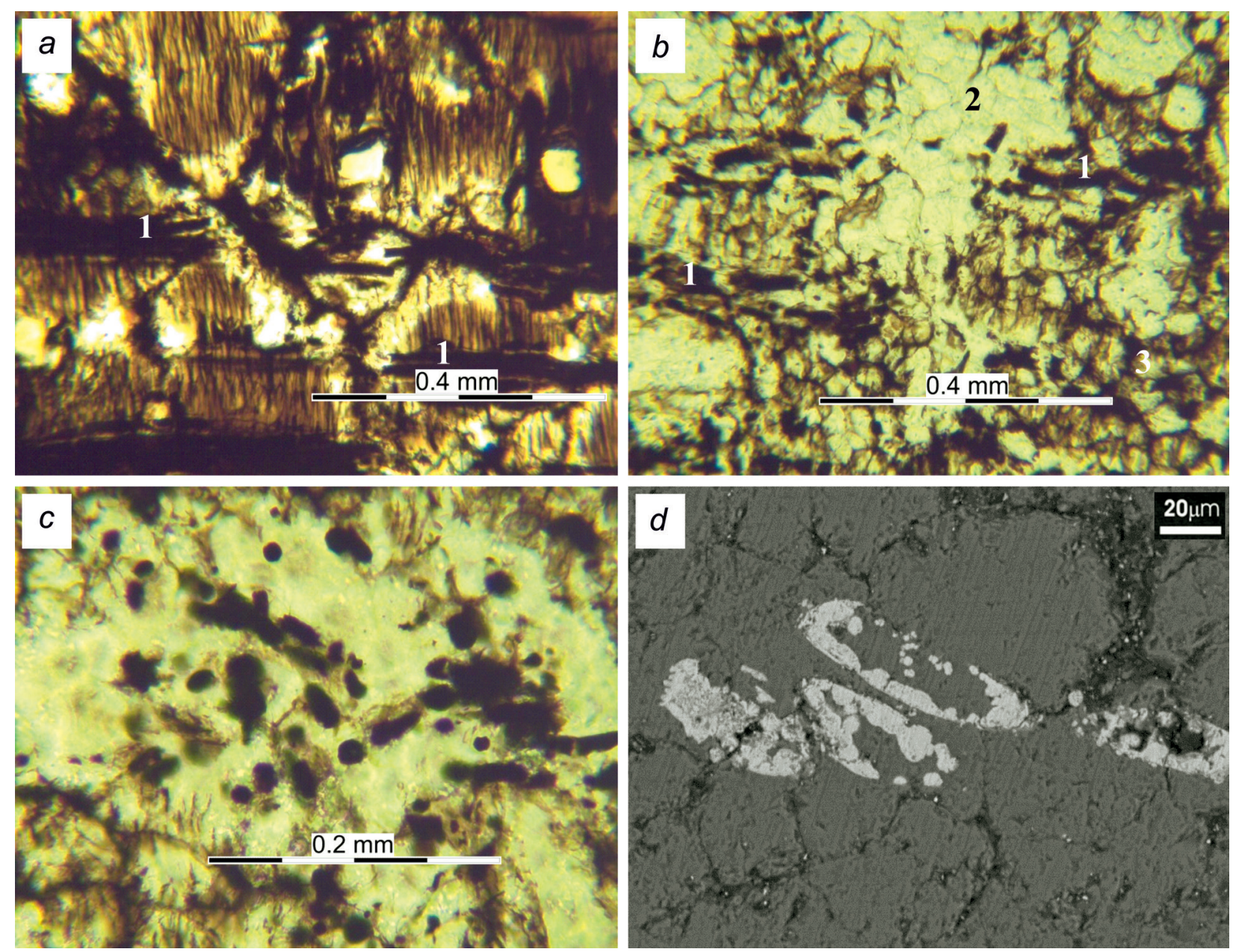

Fig. 11. Photomicrographs (plane-polarized light) of different areas of the third subzone of the superficial crust (see also Fig. 10a): a) area with newly formed quartz, chalcedony, broken rays (1) and 'drapery' of organic matter; $b$ ) areas of recrystallized quartz (2) between deformed quartz rosettes (3) and torn rays of organic matter; $c$ ) detail of (b) - quartz area with micrometre-sized cristobalite (bright spots) and 'drops' of organic matter; $d$ ) BSE image of skeletal pyrite between quartz crystals (dark grey).
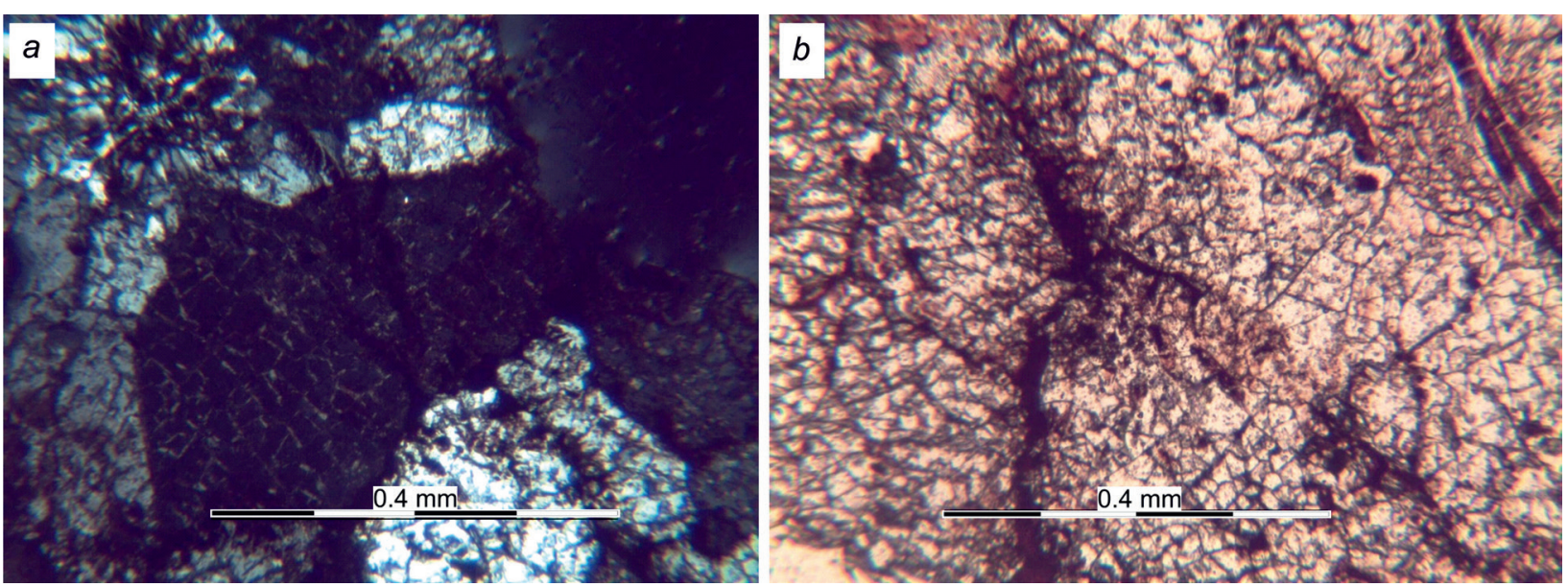

Fig. 12. a) Photomicrograph of quartz crystals from one rosette with probable deformation lamellae. $b$ ) Strongly broken quartz crystals ( $a$ - cross-polarized light; $b$ - plane-polarized light). 
ground-tissue of the tree texture, are more strongly affected (Fig. 13a, b). The melting has resulted in the formation of droplets within the deformed cells, which are presently crystallized chalcedony with black globules of organic matter. In other cases, the chalcedony is coloured by dispersed organic matter. The 'rays' of organic matter are twisted or broken (Fig. 13b, c). In some interstices, pale green quartz glass (lechatelierite) and micrometre-sized coesite crystals are found (Fig. 14). "Flow' of zoned spherules, possibly glassy (Fig. 13d), can be observed within the compact accumulations of organic matter. The smallest spherules are $40-50 \mu \mathrm{m}$ in diameter, but some can reach up to 225-250 $\mu \mathrm{m}$. The largest ones have a porous central core containing microcrystals of Fe-silicides. The periphery of the spherules is composed of almost pure, probably glassy, $\mathrm{SiO}_{2}$ (Table 3), followed by zones of likely 'organic'-Si glass with variable Si/organic matter ratio (organic matter as a difference to $100 \mathrm{wt} \%$ in ERMA), which could be close to 1:1 in their centres. In the spherules, there is a positive correlation between Ca and S ( $r=0.59, \mathrm{n}=7$ ), presumably due to the presence of gypsum and/or oldhamite, as well as positive correlation between $\mathrm{S}$ and the organic matter $(r=0.90)$.

Within the organic matter, there are microcrystals of Fe-silicides, ellipsoid forms of skeletal gypsum crystals, 'flows' of framboidal pyrite and other sulphides (see below).

\section{MINERALOGY}

\section{$\mathrm{SiO}_{2}$ minerals and glass}

The most common $\mathrm{SiO}_{2}$ mineral is quartz, presented in two generations. The first one forms the rosettelike aggregates, which build up the whole rock block.
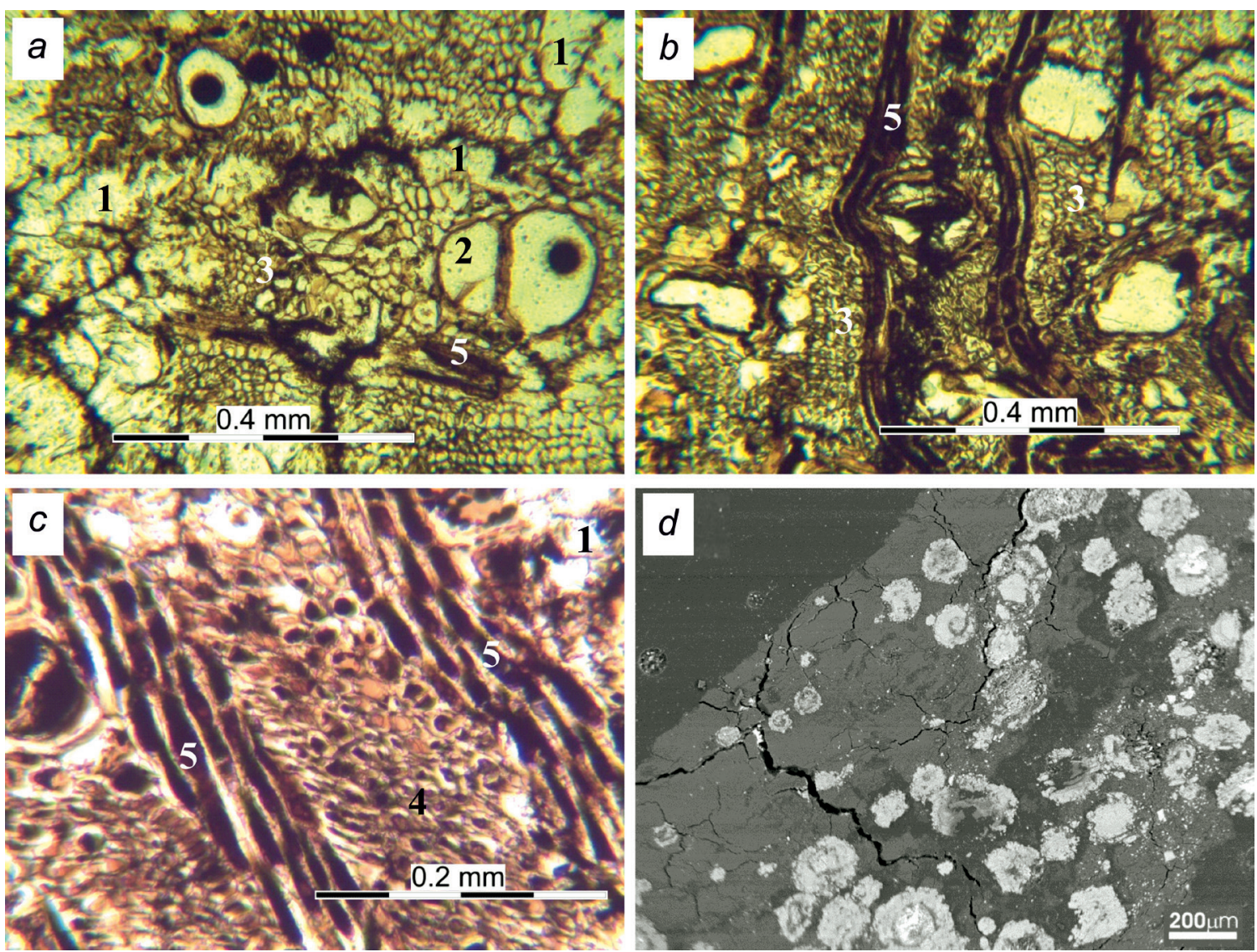

Fig. 13. $a, b, c$ ) Photomicrographs (plane-polarized light) of different cases of deformation and melting of wood relicts in the porous lenses: 1 - quartz rosettes; 2 - chalcedony globules with droplets of organic matter; 3 - parenchyma cells of deformed wood texture, partly replaced by quartz; 4 - deformed parenchyma cells filled with organic matter; 5 - broken and/or deformed rays of organic matter. $d$ ) BSE image of zoned silica-organic spherules (see Table 3 for their composition) in the organic matter compact accumulation having heterogeneous composition. 


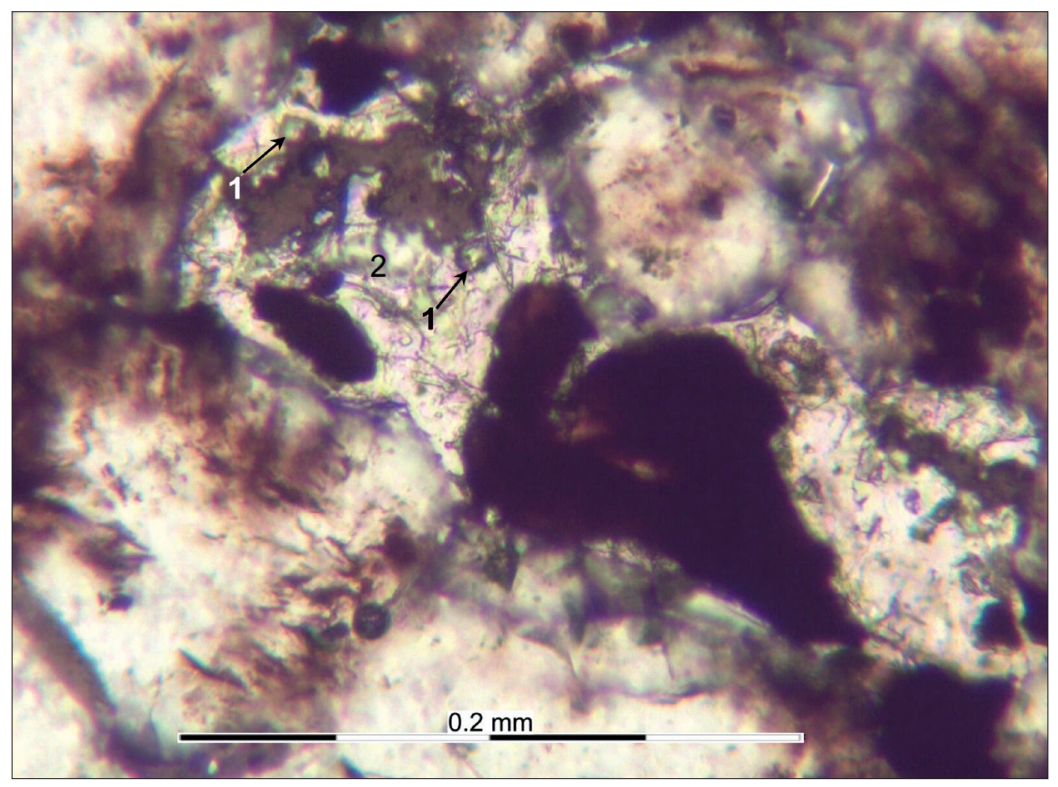

Fig. 14. Coesite crystals (1) and pale green quartz glass (lechatelierite - 2) in the interstices between the quartz rosettes in the walls of the porous lenses; the black is organic matter (plane-polarized light).

Table 3

Microprobe analyses (wt\%) of the spherules in the compact accumulations of organic matter of the Koshava exotic rock block

\begin{tabular}{lcrrr|rrr}
\hline \multirow{2}{*}{ Oxides } & \multicolumn{4}{c}{ First spherule } & \multicolumn{3}{c}{ Second spherule } \\
\cline { 2 - 8 } & \multicolumn{1}{c}{1} & \multicolumn{1}{c}{2} & \multicolumn{1}{c}{3} & \multicolumn{1}{c}{4} & \multicolumn{1}{c}{1} & \multicolumn{1}{c}{2} & \multicolumn{1}{c}{3} \\
\hline $\mathrm{SiO}_{2}$ & 98.32 & 17.04 & 48.63 & 46.67 & 91.75 & 68.37 & 71.39 \\
$\mathrm{Al}_{2} \mathrm{O}_{3}$ & 1.07 & 0.38 & 1.04 & 0.97 & 1.27 & 0.89 & 1.18 \\
$\mathrm{Fe}_{2} \mathrm{O}_{3}$ & n.d. & 3.13 & 1.18 & 1.19 & 0.17 & 0.06 & 0.01 \\
$\mathrm{MgO}$ & n.d. & 0.04 & 0.11 & 0.10 & n.d. & 0.04 & n.d. \\
$\mathrm{CaO}$ & n.d. & 1.13 & 1.17 & 1.17 & 0.23 & 0.51 & 0.21 \\
$\mathrm{Na}_{2} \mathrm{O}$ & 0.32 & 0.49 & 1.08 & 0.94 & 0.89 & 1.12 & 0.73 \\
$\mathrm{~K}_{2} \mathrm{O}$ & n.d. & 0.34 & 0.13 & 0.13 & 0.04 & 0.28 & 0.13 \\
$\mathrm{~S}$ & 0.07 & 1.56 & 1.03 & 1.01 & 0.41 & 1.77 & 0.69 \\
$\mathrm{Cl}$ & 0.21 & 1.16 & 1.13 & 1.12 & 0.76 & 0.96 & 1.30 \\
Total & 99.99 & 25.27 & 55.50 & 53.30 & 95.52 & 74.00 & 75.64 \\
\hline
\end{tabular}

1 - periphery; 2, 3 - intermediate bands; 4 - center

It is $\alpha$-quartz according to the X-ray diffraction analysis (Fig. 15, Yanev et al., 2015). The crystals have automorphic and hypidiomorphic habitus (Fig. 16a). They contain 0.058 wt\% Na, Mg $<0.019$ wt\%, B $<57.64$ ppm, Sc $<9.23$ ppm, and Sr $<5.59$ ppm according to seven spots analysed by laser ablation. The texture shows fine, probably deformation lamellae in some crystals, not longer than $0.03 \mathrm{~mm}$ in $2-3$ directions (Fig. 12a), comprehensively cracked quartz (Fig. 12b) and crystals with undulose and mosaic extinction. The second quartz generation was formed after the melting of the quartz rosettes of the rock block surface, in the wall of the porous lenses and in some wood relicts. At some places in the crust of the block (Fig. 11b), it resembles the polycrystalline aggregate of ballen quartz with sharp rim as the ones reported by Schmitt et al. (2003) from Chicxulub and by Ferrière et al. (2010) from the Mien craters.

The oxygen isotope composition of the quartz (Table 4, Fig. 17a) indicates its terrestrial origin as all data points are aligned near the TFL (Terrestrial Fractionation Line, Sharp et al., 2018). The sam- 


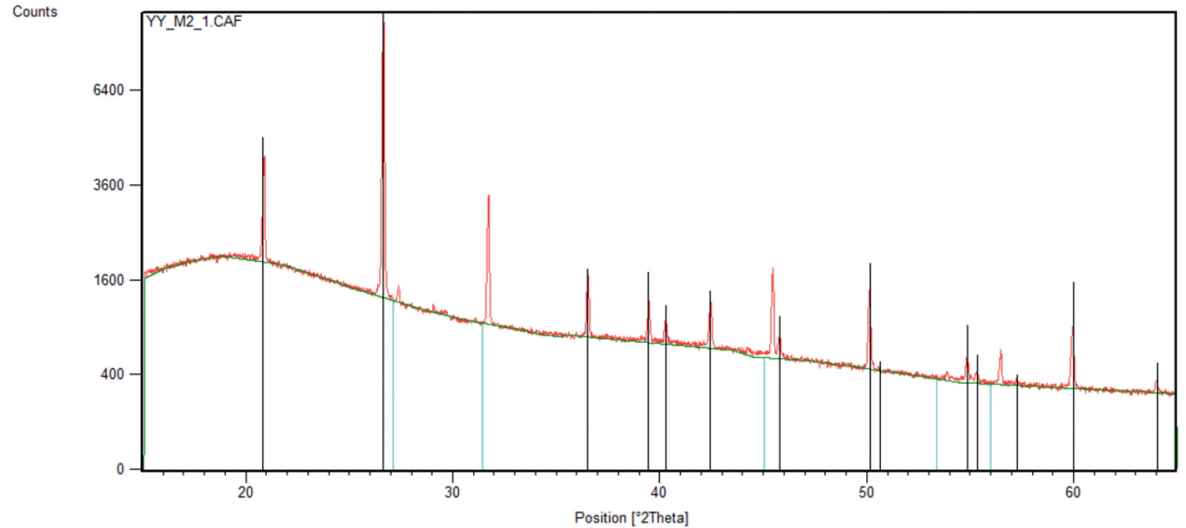

Fig. 15. X-ray diffraction patterns of sample YY-M2 from porous lenses. Black lines - $\alpha$-quartz; blue lines - hapkeite or oldhamite.
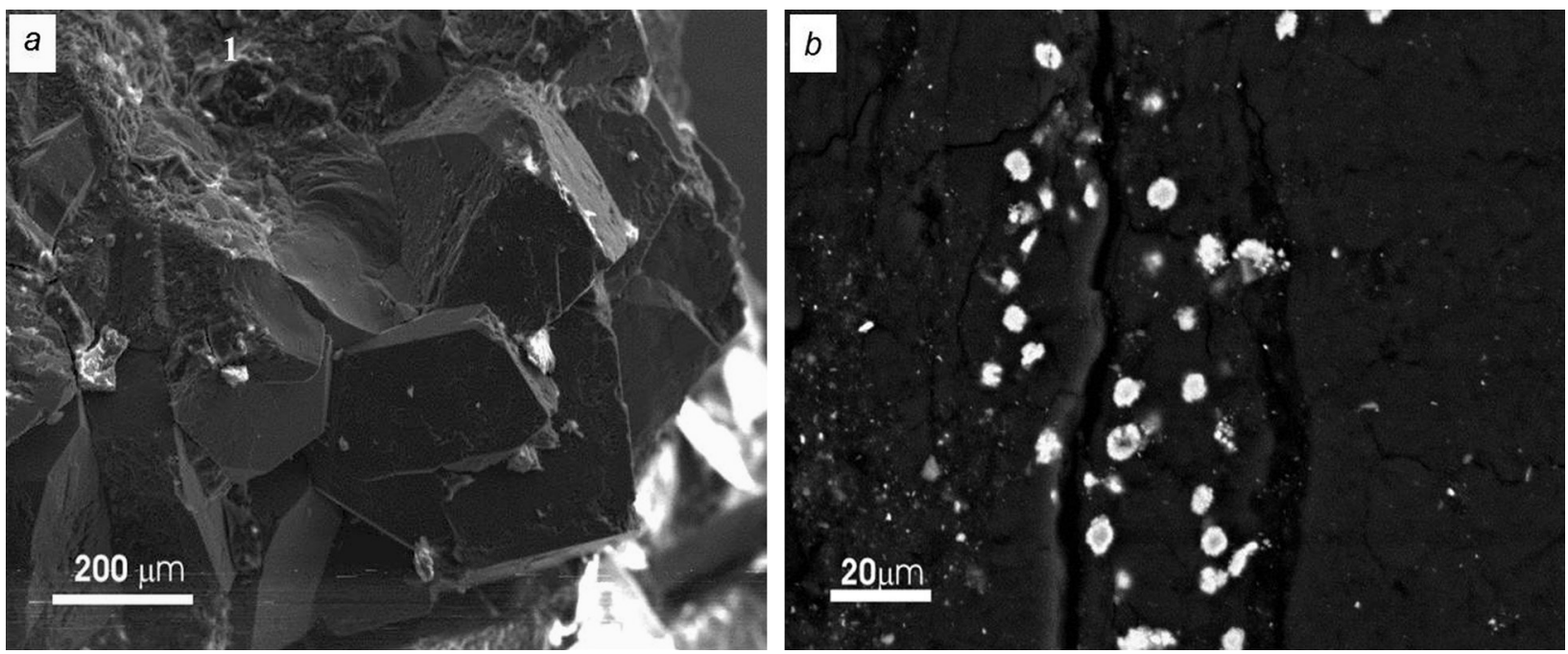

Fig. 16. a) SEM image of quartz crystals from a rosette: 1 - organic matter. $b$ ) BSE image of a 'flow' of framboidal pyrite in the organic matter compact accumulation (in the porous lenses).

ples plotted on the $\delta^{\prime 18} \mathrm{O}$ vs $\Delta^{\prime 17} \mathrm{O}$ diagram (Fig. $17 b$ ) are near the field of sedimentary quartz and calcite. However, their $\delta^{18} \mathrm{O}$ and $\delta^{17} \mathrm{O}$ values are very high.

The chalcedony variety is widely spread as veinlets or lenses, droplets in the rosette centres and mainly in wood relicts (Fig. 6) as replacement of the glass, which is mostly formed in the melting process of the petrified wood relicts in the inner parts of the rock block (Fig. 13a, c).

Cristobalite micrometre-sized crystals occur with the quartz, which formed in the molten zones of the superficial crust and regmaglypt-like forms (Figs 10d,11c), as well as around the relicts of the wood texture (Fig. 6d). It was confirmed with X-ray diffraction analysis of the heavy fraction.
Table 4

Oxygen isotope composition of quartz from the Koshava exotic rock block (YY-M1 sample)

\begin{tabular}{ccc}
\hline$\delta^{18} \mathrm{O}, \%$ о & $\delta^{17} \mathrm{O}, \%$ о & $\mathrm{R}\left({ }^{17} \mathrm{O} /{ }^{18} \mathrm{O}\right)$ \\
\hline 29.16 & 15.18 & 0.521 \\
28.66 & 14.98 & 0.523 \\
28.27 & 14.73 & 0.521 \\
28.28 & 14.81 & 0.524 \\
\hline
\end{tabular}

Coesite, in the absence of the microRaman spectrum, is determined only by optical characteristics of a mineral composed of $\mathrm{SiO}_{2}$ (determined by ERMA). It was observed in some interstices 


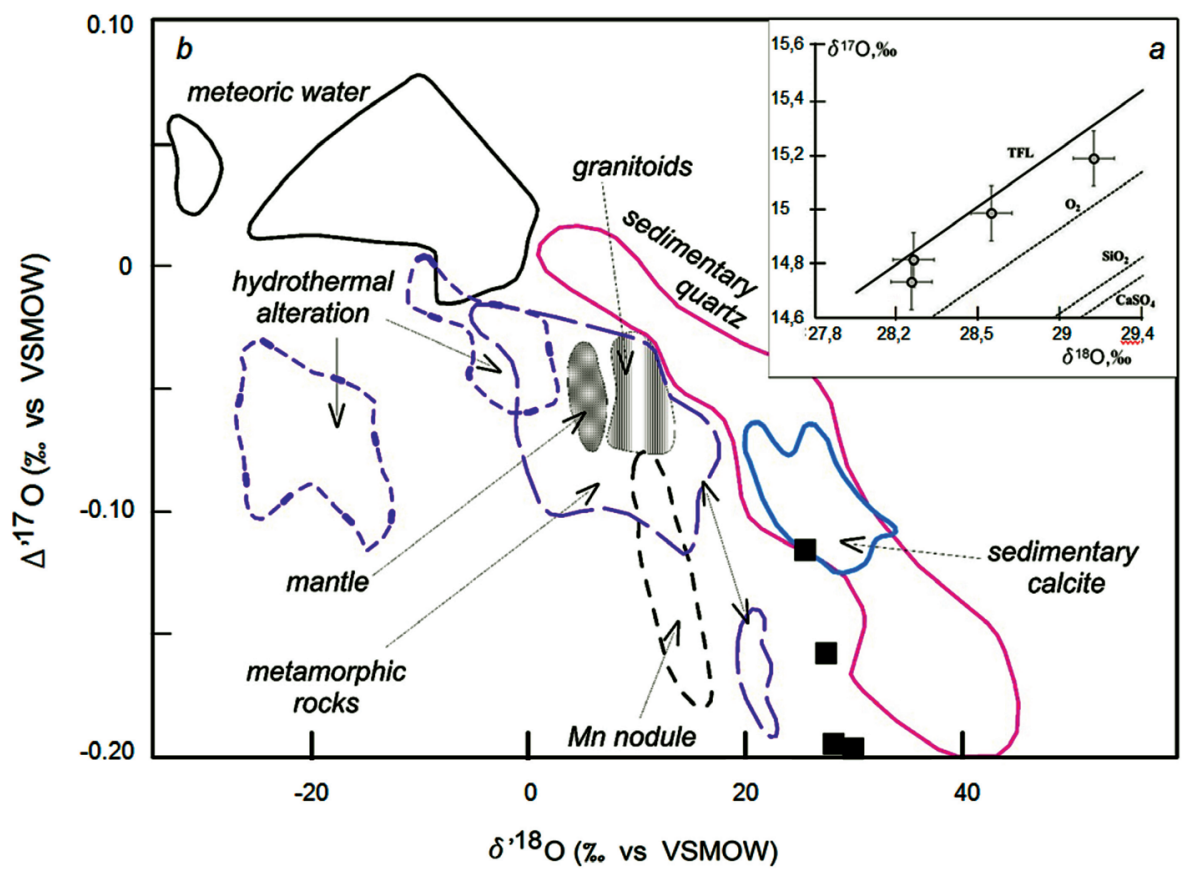

Fig. 17. a) Quartz oxygen isotope composition from the Koshava rock block (Dubinina et al., 2018). The Terrestrial Fractionation Line (TFL) is drawn according to the equation $\delta^{17} \mathrm{O}=0.5266 \times \delta^{18} \mathrm{O}-0.054$ (Sharp et al., 2018). The dashed lines were calculated according to the equation of mass-dependent kinetic isotope fractionation (Young et al., 2002) during evaporation of $\mathrm{O}_{2}$, $\mathrm{SiO}_{2}$ and $\mathrm{CaSO}_{4}$. b) $\delta^{\prime 18} \mathrm{O}$ vs $\Delta^{\prime 17} \mathrm{O}$ diagram with characteristic fields of different terrestrial materials (after Scharp et al., 2018) and position of the studied quartz samples of the Koshava rock block (black squares).

between the quartz rosettes (Fig. 14) in the most melted part of the rock block - and in the walls of the porous lenses. It represents micrometre-sized isometric and rounded crystals with high relief and comes together with lechatelierite. Its rounded crystals resemble the coesite inclusions in cristobalite and in garnet shown respectively by Ferrière et al. (2010) and Schönig et al. (2019). Coesite was also found by X-ray diffraction analysis in the heavy fraction.

Lechatelierite (quartz glass) is optically proven, as well as by microprobe analysis. It has pale green colour, probably due to the presence $\mathrm{Fe}^{2+}$ ions in the glass structure. Similar colour has the lechatelierite in, e.g., the uranium mine Vale da Vilariça, Bragança, Portugal (mindat.org).

\section{Silicides}

Numerous very fine $(<5 \mu \mathrm{m})$ crystals of silicides, mainly of Fe, but also Fe-Ni and Fe-Zn (Yanev et al., 2016b), are observed around the organic matter between the quartz rosettes (Fig. 3d), in the crust (Fig. 10b, $c$ ) and within the compact agglomerations of organic matter of the porous lenses (Fig. 8). Other phases and alloys were also analysed; however, additional studies are needed for confirmation.

\section{Fe silicides}

Out of the four stable phases known in the Fe-rich half of the Fe-Si phase diagram (e.g., Kubaschewski, 1982; Lacaze and Sundman, 1991), three minerals were analysed between the quartz crystals in the crust of the Koshava rock block (Table 5): gupeiite $\mathrm{Fe}_{3} \mathrm{Si}$, hapkeite $\mathrm{Fe}_{2} \mathrm{Si}$ and probably naquite $\mathrm{FeSi}$ (or fersilicite); the latter two melt congruently with eutectic points at $1200^{\circ} \mathrm{C}$ and $1203^{\circ} \mathrm{C}$. Only hapkeite was confirmed in the porous lenses by X-ray diffraction analysis (Fig. 15, Yanev et al., 2015), having a cell parameter $\mathrm{a}_{0}=2.818 \AA$. The area on the binary Fe-Si diagrams between pure Fe and the $\alpha_{2}$ phase (Si $11.17 \mathrm{wt} \%$ ) is the field of a disordered phase where we have found many $\mathrm{Fe}_{\mathrm{x}} \mathrm{Si}$ alloys with Si content from $3.57 \mathrm{wt} \%$ to $9.08 \mathrm{wt} \%$. Most of the analysed Fe silicides also contain Ca up to 0.38 $w t \%$. The Fe silicides have different origin, but they are common in the residue of spontaneous combustion of coal (Kruszewski et al., 2014). 
Table 5

Microprobe analyses of Fe silicides (wt\%)

\begin{tabular}{|c|c|c|c|c|c|c|c|c|c|}
\hline Mineral & Naquite & Hapkeite & Gupeiite & \multicolumn{6}{|c|}{$\mathrm{Fe}_{x} \mathrm{Si}$} \\
\hline Location & \multicolumn{7}{|c|}{ superficial crust } & \multicolumn{2}{|c|}{$\begin{array}{c}\text { compact organic } \\
\text { matter }\end{array}$} \\
\hline $\mathrm{Si}$ & 30.15 & 21.70 & 14.07 & 9.08 & 6.84 & 5.78 & 5.23 & 9.50 & 3.57 \\
\hline $\mathrm{Fe}$ & 67.95 & 77.89 & 85.42 & 90.60 & 92.42 & 94.01 & 94.38 & 90.50 & 96.43 \\
\hline $\mathrm{Ca}$ & 1.22 & 0.41 & 0.51 & 0.28 & 0.38 & 0.22 & 0.38 & n.d. & n.d. \\
\hline $\mathrm{K}$ & 0.23 & n.d. & n.d. & 0.05 & 0.12 & n.d. & 0.02 & n.d. & n.d. \\
\hline S & 0.44 & n.d. & n.d. & 0.03 & 0.16 & n.d. & n.d. & n.d. & n.d. \\
\hline
\end{tabular}

\section{Fe-Ni silicide}

There is only one stable phase in this system (Ackerbauer et al., 2009) that corresponds to the suessite $(\mathrm{Fe}, \mathrm{Ni})_{3} \mathrm{Si}$, forming on the $\mathrm{Fe}-\mathrm{Ni}$-Si diagram a large field with varying $\mathrm{Fe} / \mathrm{Ni}$ ratio between the gupeiite and $\mathrm{Ni}_{31} \mathrm{Si}_{12}$ phase. We analysed one grain in the organic matter between quartz rosettes (Table 6).

\section{Fe-Zn phases}

There are many phases in the Fe-Si-Zn system, all subsolidus, with varying compositions 'suggesting that these are solution compounds with relatively wide homogeneity ranges' (Sha et al., 2010). It is not known any natural Fe-Zn phase, but we found (Table 6) the phases $\Gamma\left(\mathrm{Fe}_{3} \mathrm{Zn}_{7}\right)$ and $\delta\left(\mathrm{FeZn}_{10}\right)$, formed below $782{ }^{\circ} \mathrm{C}$ and $529^{\circ} \mathrm{C}$, respectively. Their elevated Si content is probably due to the presence of $\mathrm{FeSi}$ or/and $\alpha$-Fe nanoparticles (Wang et al., 2005), the latter having very high Si solubility.

\section{Sulphides}

Single small crystals of sphalerite occur within the quartz rosettes and skeletal sphalerite, in the compact agglomerations of organic matter.

Mn-containing skeletal pyrite is revealed in the molten crust on the surface of the block (Fig. 11d) with some zoned crystals (average composition in $\mathrm{wt} \%, \mathrm{n}=6: 45.74 \mathrm{Fe}, 53.89 \mathrm{~S}$, and up to $1.24 \mathrm{Mn}$ in the outer zones). 'Flow' of framboidal pyrite (average composition in $w t \%, n=3: 47.76$ Fe, 52.24 S) are observed in the organic matter of the porous lenses (Fig. 16b); the diameter of the crystals is 5-6 $\mu \mathrm{m}$ on the average; rarely up to $10-11 \mu \mathrm{m}$. The genesis of the framboidal pyrite can be quite diverse (Scott et al., 2009).

The organic matter also contains other sulphides with Fe:S ratio $\sim 1: 1$ and greigite (56.61 $\mathrm{wt} \% \mathrm{Fe}$, $43.19 \mathrm{wt} \% \mathrm{~S}$, and $0.10 \mathrm{wt} \% \mathrm{Mn})$. X-ray diffraction analysis of bulk sample from the porous part of the
Table 6

Microprobe analyses of suessite and $\mathrm{Fe}-\mathrm{Zn}$ phases (at.\%)

\begin{tabular}{lccc}
\hline \multirow{2}{*}{ Elements } & Suessite & \multicolumn{2}{c}{ Fe-Zn phases } \\
\cline { 3 - 4 } & & $\delta$ & $\Gamma$ \\
\hline $\mathrm{Si}$ & 18.61 & 5.42 & 4.60 \\
$\mathrm{Ti}$ & 0.39 & n.d. & n.d. \\
$\mathrm{Al}$ & 4.35 & n.d. & n.d. \\
$\mathrm{Fe}$ & 55.03 & 13.47 & 71.57 \\
$\mathrm{Ca}$ & 3.99 & 0.59 & 0.64 \\
$\mathrm{~K}$ & 0.18 & 0.13 & n.d. \\
$\mathrm{Ni}$ & 17.45 & n.d. & n.d. \\
$\mathrm{Zn}$ & n.d. & 80.39 & 23.19 \\
\hline
\end{tabular}

rock block (sample YY-M2) showed the presence of oldhamite and/or hapkeite, which have similar diffraction patterns (Fig. 15); however, we do not have a reliable ERM analysis to confirm the presence of oldhamite.

\section{Sulphates}

Gypsum is the most common sulphate mineral in the studied rock (average composition in atom\%, $\mathrm{n}$ = 4: $45.98 \mathrm{~S}, 47.18 \mathrm{Ca}, 4.25 \mathrm{Na}, 1.32 \mathrm{Sr}, \mathrm{K}<1.28$ ). It is in the form of 5-7 $\mu \mathrm{m}$ long skeletal crystals in the compact agglomerations of organic matter, veinlets or porous aggregates in the fissures of the block, and within cavities. In the latter, celestine was determined by X-ray diffraction analysis. This mineral is widely spread in the Koshava gypsum deposit (Trashliev and Boyadzhiev, 1966). One crystal of barite was also found.

There are also calcite, halite and some clays (kaolinite and mixed layered clay minerals), which were proved by X-ray diffraction analysis of bulk samples, and graphite in the quartz rosettes, proved by IR spectroscopy (Fig. $5 b$ ). In the heavy fraction were found single grains of moissanite (optically 
determined by V. Arnaudov, Geological Institute, BAS), magnetite and probably fayalite.

\section{DISCUSSION AND CONCLUSIONS}

The microscopic characterization of the investigated Koshava rock block (relicts of wood texture and lenses of compact organic matter) allows for the assumption that it is a petrified wood fragment oak, according to S. Iamandei (pers. comm.). It is quartzified to a varying degree: with large areas of fully crystallized quartz rosettes (Fig. 3a, b) similar to those described by Hassan (2014); through relict areas of chalcedony replacement (Fig. 6) similar to those described by Iamandei et al. (2014) in the Eastern Rhodopes; and relicts of carbonized porous lenses (Fig. $7 a, b$ ). The organic matter has been 'extruded' into the interstices during the process of crystal growth of the quartz rosettes. It was impossible to determine which of the other minerals existed in the petrified wood before the successive transformations.

Following the re-crystallization in the petrified and partially coalified wood, the rock block had been subjected to intense melting, with temperatures exceeding $1700^{\circ} \mathrm{C}$ and accompanied by shock. The melting of the surface resulted in the formation of molten $\mathrm{SiO}_{2}$ envelope with regmaglypt-like forms (Figs $2 a, 10$ ). Within the inner part of the block, melting occurred in the interstices between the quartz rosettes (Fig. 3c), with lechatelierite and coesite formed in some places (Fig. 14), but mainly in the petrified (by chalcedony) wood relicts (Figs 6, 13). The compact organic matter in the porous lenses and the organic matter between the quartz rosettes is amorphized, forming 'micro-furnaces' (dimensions from tens to some hundreds of micrometres) with fused quartz 'walls' (Fig. 3d) where Fe-silicides, suessite, moissanite and possibly diverse alloys (Yanev et al., 2016a) crystallized at $\sim 1200{ }^{\circ} \mathrm{C}$ in reducing conditions (probably at the Fe-fayalitequartz buffer and lower). Si-organic zoned spherules, possibly glassy, formed in the compact accumulation of organic matter (Fig. 13d).

The presence of both features, extensive high temperature melting (melted quartz rosettes with formation of ballen-like quartz, melted wood relicts, superficial crust with regmaglypts, lechatelierite, high temperature minerals as silicides, moissanite, melting spherules) and shock impact (coesite, strongly broken quartz, deformation lamellae in them, high $\delta^{18} \mathrm{O}$ values of quartz), allow for the assumption that the Koshava rock block is a tektite, shock ejecta of a meteorite impact. The absence of any other terrigenous sediments whatsoever in the homogeneous gypsum layer excludes the possibility that the presented rock block is a material deposited in a sedimentation process. It resembles tektites of the Muong Nong-type (described by Wasson, 1991, Schnetzler, 1992, and others), which are characterized by relatively large size, block structure (but layered), presence of glass crust, internal heterogeneity with unmolten and molten parts, lack of aerodynamic shape, and high concentration of volatile components. However, there are several differences: the studied rock block is considerably larger, the molten glass is completely crystallized, the relicts are significantly prevalent over the molten parts, and the presence of organic matter.

Assuming that the Koshava rock block was a tektite, during its flight the molten shell solidified to silica glass, which had preserved the vaporization of the organic matter in the interior of the rock fragment. After falling into the gypsum lagoon (now Koshava deposit) and rapid cooling, the glassy envelope of the block crystallized by forming fine hypidiomorphic quartz, while the glass inside the block crystallized as chalcedony. Framboidal pyrite, other sulphides and possibly some of the sulphates (skeletal gypsum, barite) crystallized in the organic matter. Porous gypsum, celestine, calcite, halite and clay minerals formed within fissures and cavities in the block when normal temperatures were reached in the gypsum lagoon.

The proposed origin of the Koshava rock block can explain its heavy oxygen isotope composition and its 'scattered' values (Dubinina et al., 2018). Such composition can be due to kinetic isotope fractionation through partial degassing of the sediment substrate during the impact event. For example, during the partial dehydration of some terrestrial and meteorite minerals, both $\delta^{18} \mathrm{O}$ and $\delta^{17} \mathrm{O}$ values of silicate rests are increased with the extent of the dehydration increase (Clayton and Mayeda, 2009). The Koshava isotopic data are slightly lower than TFL (Fig. 17a). According to the calculation of mass-dependent kinetic isotope fractionation (Young et al., 2002) during evaporation of $\mathrm{SiO}_{2}, \mathrm{O}_{2}$ and $\mathrm{CaSO}_{4}$, the data points should be moved in this direction.

The age of the Koshava gypsum layer can be used to estimate the time of the impact, to which the described rock block is likely to be related. Unfortunately, such age has not been palaeontologically exactly established, nor by isotope analysis. It is only known that the gypsum layer overlies lower-middle Badenian and underlies upper Badenian sediments, 
the latter deposited after an erosion period (Kojumdgieva et al., 1982). The formation of gypsum is associated with the middle Badenian salt crisis, generally accepted to have occurred in the 15-14 Ma age interval (Peryt, 2006). Based on that, we can assume as a possible source of this rock block only the Ries-Steinheim impact event (e.g., Engelhardt, 1990; Stöffler et al., 2002, 2013). It occurred in the early-middle Badenian, according to the scale of Hohenegger et al. (2014), 14.88 \pm 0.11 Ma (Abdul Aziz et al., 2008). However, the Koshava gypsum deposit is located $\sim 1100 \mathrm{~km}$ to the southeast from that impact site (Fig. 18a), oblique to the supposed northeastern direction of the meteorite impact (Stöffler et al., 2002).

The exact timing and place of tektite formation relative to impact events is generally not known (Koeberl, 2003; French and Koeberl, 2010). However, we can assume that the petrified wood of the Koshava rock block was ejected from the spall zone of the impact crater. According to Glass and Simonson (2013), 'the spall zone [...] is a region near the surface where large blocks of unshocked or weakly shocked target rock can be accelerated to high velocities'. In the Ries-Steinheim impact site, this zone was within unconsolidated lacustrine-fluvial sediments on the northern coast of the Bavarian Molasse Sea, early-middle Miocene in age (Engel- hardt, 1990; Stöffler et al., 2013). This molasse is one of the richest in silicified woods in the world (Böhme et al., 2007). The silicified wood may have been blown away together with other loose Miocene sediments by the front wave, propagating ahead of the meteorite (i.e., before the impact), or in the first moment of the impact, i.e., during the first phase determined by Stöffler et al. (2013) as 'Projectile impact, shock wave propagation, and formation of distal ejecta'. The other tektites, moldavites, that formed from molten sand were dispersed along the direction of the meteorite impact, i.e., mainly to the northeast (Fig. 18a), while the silicified wood piece (Koshava rock block) was ejected to the southeast. Its trajectory probably reached several hundred kilometers in height, based on extrapolation of the graph in the tektite flight model of Stöffler et al. (2002). In such ballistic mode of transport, this rock block would have been subjected to melting twice, as it crossed the atmosphere twice.

It is acknowledged that the 'flight' distance to the Koshava gypsum deposit is very long. However, it should be noted that some large Muong Nong tektites $(>1 \mathrm{~kg})$ were found in an area with minimum dimensions of $800 \times 1140 \mathrm{~km}$ (Wasson, 1991). As a result of the oblique impact, they spread in three directions and tektite strewn fields formed 'butterfly wings' (Whymark, 2016; Hildebrand, 2019). For

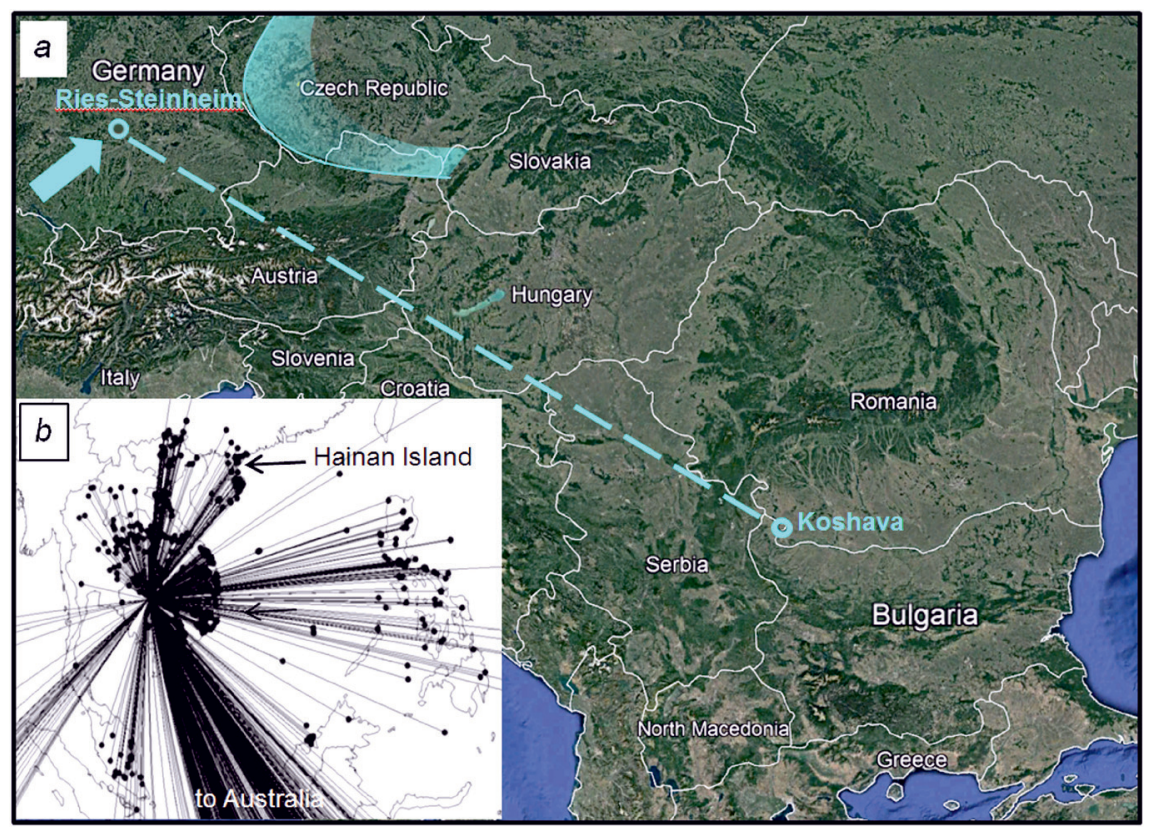

Fig. 18. a) Google map image of Central and SE Europe with location of the Ries-Steinheim impact site and the Koshava gypsum mine. The blue arrow shows the direction of the presumed meteorite shock (after Stöffler et al., 2013), and the blue shaded area shows the moldavite tektites' strewn field. b) Sketch of SE Asia and the places of Australian tektites. The lines (after Whymark, 2016) connect the tektite places with one of the hypothetic impact sites in Indochina. See text for explanations. 
example, the Wenchang tektite, weighing $10.79 \mathrm{~kg}$, was found on Hainan Island, China (Futrell and Wasson, 1993), which is $750 \mathrm{~km}$ to the northeast (Fig. 18b), in a direction perpendicular to the supposed meteoritic impact. Similar spread show the projectiles of the Imbrium Sculpture on the Moon (Schultz and Crawford, 2016), as well as the experiments on oblique impacts (Moore, 1976, p. B.8).

The characteristics of the Koshava rock block (large size, completely crystallized glass, prevalence of unmolten relict zones, presence of organic matter) could be the basis for distinguishing it as a new tektite type shock ejecta.

\section{Acknowledgements}

We thank Konstantin Antov, mining master, and Goran Tsvetkov, chief mining engineer of the Ko- shava mine, for providing the samples. We are grateful to: George D. Kamenov (University of Florida, U.S.A.), Prof. Stanila Iamandei (Geological Institute of Romania) and Petko Petrov (National Museum 'Earth and Man', Sofia, Bulgaria) for productive discussions; Rayna Todorova (Institute of Organic Chemistry, Bulgarian Academy of Sciences) for analyses of major elements of organic matter; Metodi Karadjov (Geological Institute, Bulgarian Academy of Sciences) for preparation of the heavy fraction; Vasil Arnaudov (Geological Institute, Bulgarian Academy of Sciences) for some mineralogical determinations; Svetlana Encheva (National Museum 'Earth and Man', Sofia, Bulgaria) for providing the photomicrographs; and Simeon Waltscheff for translating the manuscript into English. Two anonymous reviewers are acknowledged for useful critical reviews of the text.

\section{REFERENCES}

Abdul Aziz, H., Böhme, M., Rocholl, A., Zwing, A., Prieto, J., Wijbrans, J.R., Heissig, K., Bachtadse, V. 2008. Integrated stratigraphy and ${ }^{40} \mathrm{Ar} /{ }^{39} \mathrm{Ar}$ chronology of the Early to Middle Miocene Upper Freshwater Molasse in eastern Bavaria (Germany). International Journal of Earth Sciences 97 (1), 115-134, https://doi.org/10.1007/s00531006-0166-7.

Ackerbauer, S., Krendelsberger, N., Weitzer, F., Hiebl, K., Schuster, J.C. 2009. The constitution of the ternary system Fe-Ni-Si. Intermetallics 17 (6), 414-420, https://doi. org/10.1016/j.intermet.2008.11.016.

Böhme, M., Bruch, A.A., Selmeier, A. 2007. The reconstruction of Early and Middle Miocene climate and vegetation in Southern Germany as determined from the fossil wood flora. Palaeogeography, Palaeoclimatology, Palaeoecology 253 (1-2), 91-114, https://doi.org/10.1016/j.palaeo.2007.03.035.

Boynton, W.V. 1984. Geochemistry of the rare earth elements: meteorite studies. In: Henderson, P. (Ed.), Rare Earth Element Geochemistry. Elsevier, Amsterdam, 63-114, https:// doi.org/10.1016/B978-0-444-42148-7.50008-3.

Bussemann, H., Alexander, C.M.O.D., Nittler, L.R. 2007. Characterization of insoluble organic matter in primitive meteorites by microRaman spectroscopy. Meteoritics \& Planetary Sciences 42 (7-8), 1387-1416, https://doi. org/10.1111/j.1945-5100.2007.tb00581.x.

Clayton, R.N., Mayeda, T.K. 2009. Kinetic isotope effects in oxygen in the laboratory dehydration of magnesian minerals. The Journal of Physical Chemistry A 113 (10), 2212 2217, https://doi.org/10.1021/jp808621n.

De Leeuw, A., Bukowski, K., Krijgsman, W., Kuiper, K.F. 2010. Age of the Badenian salinity crisis; impact of Miocene climate variability on the circum-Mediterranean re- gion. Geology 38 (8), 715-718, https://doi.org/10.1130/ G30982.1.

Dubinina, E.O., Yanev, Y., Benderev, A. 2018. Oxygen isotope composition of quartz from the Koshava tektite, NW Bulgaria. Review of the Bulgarian Geological Society 79 (3), 43-44.

Engelhardt, W. von. 1990. Distribution, petrography and shock metamorphism of the ejecta of the Ries crater in Germany - a review. Tectonophysics 171 (1-4), 259-273, https://doi. org/10.1016/0040-1951(90)90104-G.

Ferrière, L., Koeberl, C., Libowitzky, E., Reimold, W.U., Greshake, A., Brandstätter, F. 2010. Ballen quartz and cristobalite in impactites: New investigations. In: Gibson, R.L., Reimold, W.U. (Eds), Large Meteorite Impacts and Planetary Evolution IV. Geological Society of America Special Paper 465, 609-618, https://doi. org/10.1130/2010.2465(29).

French, B.M., Koeberl, C. 2010. The convincing identification of terrestrial meteorite impact structures: What works, what doesn't, and why. Earth-Science Reviews 98, 123-170, https://doi.org/10.1016/j.earscirev.2009.10.009.

Fröhlich, F., Poupeau, G., Badou, A., Le Bourdonnec, F.X., Sacquin, Y., Dubernet, S., Bardintzeff, J.-M., Véran, M., Smith, D.C., Diemer, E. 2013. Libyan Desert Glass: New field and Fourier transform infrared data. Meteoritics \& Planetary Sciences 48 (12), 2517-2530, https://doi. org/10.1111/maps.12223.

Futrell, D.S., Wasson, J.T. 1993. A 10.8-kg layered (Muong Nong-type) tektite from Wenchang, Hainan, China. Meteoritics \& Planetary Sciences 28 (1), 136-137, https://doi. org/10.1111/j.1945-5100.1993.tb00259.x.

Glass, B.P., Simonson, B.M. 2013. Distal impact ejecta layers. A record of large impacts in sedimentary deposits. 
Springer-Verlag, Berlin Heidelberg, 716 pp, https://doi. org/10.1007/978-3-540-88262-6_11.

Goldbeck, O.K. von. 1982. Iron-silicon. In: Iron-Binary Phase Diagrams. Springer-Verlag, Berlin-Heidelberg, 136-139, https://doi.org/10.1007/978-3-662-08024-5_62.

Hassan, K.M. 2015. The fossil wood of East Cairo, Egypt: A mineralogical view. Mineralogia 45 (1-2), 47-57, https:// doi.org/10.1515/mipo-2015-0003.

Hildebrand, A.R. 2019. The highly oblique source impact of the Australasian tektite strewn field in Champasak Province, Laos. 50th Lunar and Planetary Science Conference 2019, Abstracts, p. 3116.

Hohenegger, J., Ćorić, S., Wagreich, M. 2014. Timing of the Middle Miocene Badenian Stage of the Central Paratethys. Geologica Carpathica 65 (1), 55-66, https://doi. org/10.2478/geoca-2014-0004.

Iamandei, S., Iamandei, E., Bozukov, V., Tsenov, B. 2014. Oligocene fossil wood from Rhodopes, Bulgaria. Acta Palaeontologica Romaniae 9, 2, 15-25.

Ketris, M.P., Yudovich, Ya.E. 2009. Estimations of Clarkes for carbonaceous biolithes: World averages for trace element contents in black shales and coals. International Journal of Coal Geology 78 (2), 135-148, https://doi.org/10.1016/j. coal.2009.01.002.

Koeberl, Ch. 2003. Tektites (1.28.4.3). In: Holland, H.D., Turekian, K. (Eds), Treatise on Geochemistry, Vol. 1. Meteorites, Comets, and Planets. Elsevier, Amsterdam, 29-30.

Kojumdgieva, E., Stancheva, M., Dikova, P. 1982. Reference sections of the Neogene in boreholes from Northwestern Bulgaria. Paleontology, Stratigraphy and Lithology 25, 49-60 (in Bulgarian, with English abstract).

Krätschmer, W., Lamb, L.D., Fostiropoulos, K., Huffman, D.R. 1990. Solid $\mathrm{C}_{60}$ : a new form of carbon. Nature 347 (6291), 354-358, https://doi.org/10.1038/347354a0.

Kruszewski, Ł., Ciesielczuk, J., Misz-Kennan, M., Fabiańska, M. 2014. Chemical composition of glasses and associating mineral species in various pyrometamorphic rocks from coal-mining dumps of the Lower Silesia. Mineralogia Special Papers 42, 70-71.

Lacaze, J., Sundman, B. 1991. An assessment of the Fe-C-Si system. Metallurgical Transactions A 22A, 2211-2223, https://doi.org/10.1007/BF02664987.

Moore, H.J. 1976. Missile impact craters (White Sands Missile Range, New Mexico) and applications to lunar research. USGS Professional Papers 812-B, B1-B47, https://doi. org/10.3133/pp812B.

Peryt, T.M. 2006. The beginning, development and termination of the Middle Miocene Badenian salinity crisis in Central Paratethys. Sedimentary Geology 188-189, 379-396, https://doi.org/10.1016/j.sedgeo.2006.03.014.

Schmitt, R.T., Wittmann, A., Stöffler, D. 2003. The ICDP drill core Yaxcopoil-1, Chicxulub impact crater, Mexico: Shock metamorphism of the impactite units (794-894 m). Large Meteorite Impacts and Planetary Evolution Conference, Vol. 3, Abstracts, 4061.pdf.

Schnetzler, C.C. 1992. Mechanism of Muong Nong-type tektite formation and speculation on the source of Australasian tektites. Meteoritics \& Planetary Sciences 27 (2), 154-165, https://doi.org/10.1111/j.1945-5100.1992.tb00743.x.

Schönig, J., von Eynatten, H., Meinhold, G., Lünsdorf, N.K. 2019. Diamond and coesite inclusions in detrital garnet of the Saxonian Erzgebirge, Germany. Geology 47 (8), 715718, https://doi.org/10.1130/G46253.1.

Scott, R.J., Meffre, S., Woodhead, J., Gilbert, S.E., Berry, R.F., Emsbo, P. 2009. Development of framboidal pyrite during diagenesis, low-grade regional metamorphism, and hydrothermal alteration. Economic Geology 104 (8), 1143-1168, https://doi.org/10.2113/gsecongeo.104.8.1143.

Sha, C., Liu, S., Du, Y., Xu, H., Zhang, L., Liu, Y. 2010. Experimental investigation and thermodynamic reassessment of the Fe-Si-Zn system. CALPHAD: Computer Coupling of Phase Diagrams and Thermochemistry 34 (4), 405-414, https://doi.org/10.1016/j.calphad.2010.07.006.

Sharp, Z.D. 1990. A laser-based microanalytical method for the in-situ determination of oxygen isotope ratios of silicates and oxides. Geochimica et Cosmochimica Acta 54 (5), 1353-1357, https://doi.org/10.1016/00167037(90)90160-M.

Sharp, Z.D., Wostbrock, J.A.G., Pack, A. 2018. Mass-dependent triple oxygen isotope variations in terrestrial materials. Geochemical Perspective Letters 7, 27-31, https://doi. org/10.7185/geochemlet.1815.

Schultz, P.H., Crawford, D.A. 2016. Origin and implications of non-radial Imbrium Sculpture on the Moon. Nature 535 (7612), 391-394, https://doi.org/10.1038/nature18278.

Stöffler, D., Artemieva, N.A., Pierrrazzo, E. 2002. Modeling the Ries-Steinheim impact event and the formation of the moldavite strewn field. Meteoritics \& Planetary Sciences 37 (12), 1893-1907, https://doi. org/10.1111/j.1945-5100.2002.tb01171.x.

Stöffler, D., Artemieva, N.A., Wünnemann, K., Reimold, W.U., Jacob, J., Hansen, B.K., Summerson, I.A.T. 2013. Ries crater and suevite revisited - Observations and modeling. Part I: Observations. Meteoritics \& Planetary Science 48 (4), 515-589, https://doi.org/10.1111/maps.12086.

Trashliev, S. 1988. Gypsum. In: Trashliev, S. (Ed.), Nonmetallic Resources of Bulgaria, Vol. 1. Exogenic Industrial Minerals and Rocks. Tehnika, Sofia, 199-214 (in Bulgarian).

Trashliev, S., Boyadzhiev, G. 1966. Strontium distribution in the gypsum horizon in northwest Bulgaria. Review of the Bulgarian Geological Society 27 (2), 211-221 (in Bulgarian, with English abstract).

Trashliev, S., Kojumdgieva, E., Dikova, P., Deikova, Z. 1962. Stratigraphie, lithologie et caractéristique du gypse du Tortonien en Bulgarie de nord-ouest. Annuaire de la Direction générale de géologie 13, 91-134 (in Bulgarian, with French abstract).

Valley, J.W., Kitchen, N., Kohn, M.J., Niendorf, C.R., Spicuzza, M.J. 1995. UWG-2, a garnet standard for oxygen isotope ratios: Strategies for high precision and accuracy with laser heating. Geochimica et Cosmochimica Acta 59 (24), 5223-5231, https://doi.org/10.1016/00167037(95)00386-X.

Wang, J.H., Su, X., Yin, F., Li, Z., Zhao, M. 2005. The 480 ${ }^{\circ} \mathrm{C}$ and $405{ }^{\circ} \mathrm{C}$ isothermal sections of the phase diagram of Fe-Zn-Si ternary system. Journal of Alloys and Compounds 399 (1-2), 214-218, https://doi.org/10.1016/j.jallcom.2005.03.043.

Wasson, J.T. 1991. Layered tektites: a multiple impact origin for the Australasian tektites. Earth and Planetary Science Letters 102 (2), 95-109, https://doi.org/10.1016/0012821X(91)90001-X.

Whymark, A. 2016. Regression of Australasian tektite locations to published candidate source craters. $47^{\text {th }}$ Lunar and Planetary Science Conference, Abstracts, p.1073.

Wopenka, B., Pasteris, J.D. 1993. Structural characterization of kerogens to granulite-facies graphite: Applicability of Raman microprobe spectroscopy. American Mineralogist 78, 533-557. 
Yanev, Y., Benderev, A., Zotov, N., Ilieva, I., Iliev, Tz., Georgiev, S. 2015. Tektite or meteorite from Koshava gypsum mine, NW Bulgaria. Bulgarian Geological Society, $\mathrm{Na}$ tional Conference with International Participation "Geosciences 2015”, Abstracts, 81-82.

Yanev, Y., Georgiev, S., Zotov, N., Iliev, Tz., Benderev, A., Ilieva, I. 2016a. "Organic matter" in the Koshava tektite (or meteorite), NW Bulgaria - Raman and geochemical study. Bulgarian Geological Society, National Conference with International Participation "Geosciences 2016”, Abstracts, 79-80.
Yanev, Y., Iliev, Tz., Zotov, N., Benderev, A., Nihtianova, D., Ilieva, I. 2016b. Silicides and alloys from Koshava tektite (or meteorite), NW Bulgaria. Bulgarian Geological Society, National Conference with International Participation "Geosciences 2016", Abstracts, 43-44.

Young, E.D., Galy, A., Nagahara, H. 2002. Kinetic and equilibrium mass-dependent isotope fractionation laws in nature and their geochemical and cosmochemical significance. Geochimica et Cosmochimica Acta 66 (6), 1095-1104, https://doi.org/10.1016/S0016-7037(01)00832-8. 